\title{
A Gallery of Royal Effigies in Medieval Hungary and Its Genealogical Purpose
}

\author{
Vinni Lucherini
}

Playing on the concept of a gallery, I would like to draw attention to some late medieval representations in which portraits of sovereigns, ${ }^{1}$ belonging to one or more dynasties, were positioned within diachronic series in order to present a sort of genealogical history through images. ${ }^{2}$ The type of royal effigies

1 On the complex question of medieval portraiture and its fidelity to nature: Das Porträt vor der Erfindung des Porträts, eds. Martin Büchsel, and Peter Schmidt (Mainz, 2003); Stephen Perkinson, "Portraits and Counterfeits: Villard de Honnecourt and ThirteenthCentury Theories of Representation," in Excavating the Medieval Image. Manuscripts, Artists, Audiences. Essays in Honor of Sandra Hindman, eds. David S. Areford, and Nina Rowe (Aldershot, 2004), pp. 13-28; Stephen Perkinson, "Rethinking the origins of portraiture," Gesta 46/2 (2007), 135-157; Stephen Perkinson, "Likeness," Studies in Iconography 33 (2012), Special Issue Medieval Art History Today - Critical Terms, 15-28. Specially on royal portraits: Stephen Perkinson, The Likeness of the King. A Prehistory of Portraiture in Late Medieval France (Chicago, 2009). A good example: Gerhard Schmidt, "Porträt oder Typus: zur Frage der Ähnlichkeit in den Darstellungen Kaiser Friedrichs III," Jahrbuch des Kunsthistorischen Museums Wien 8/9 (2006), 10-59. See also: Set in Stone. The Face in Medieval Sculpture, exhibition catalogue, ed. Charles T. Little (New Haven, 2006); Noa Turel, "Living Pictures: Rereading 'Au Vif,' 1350-1550," Gesta 50/2 (2011), 163-82; most recently: La fantasia e la storia. Studi di Storia dell'arte sul ritratto dal Medioevo al Contemporaneo, ed. Giulio Brevetti (Palermo, 2019).

2 Regarding genealogies as symbolic forms and conceptual metaphors with the function of legitimation: Gabrielle Spiegel, "Genealogy. Form and Function in Medieval Historical Narrative," History and Theory 22/1 (1983), 43-53; Gabrielle Spiegel, "Structures of Time in Medieval Historiography," The Medieval History Journal 19/1 (2016), 21-33; Idoneität-Genealogie - Legitimation. Begründung und Akzeptanz von dynastischer Herrschaft im Mittelalter, eds. Cristina Andenna, and Gert Melville (Cologne, 2015). For classic research on this topic, see: Bernard Guenée, "Les généalogies entre l'histoire et la politique: la fierté d'être Capétien, en France, au Moyen Âge," Annales. Histoire, Sciences Sociales 33/3 (1978), 450-77; Gert Melville, "Spätmittelalterliche Genealogien als dynastische Legitimation zur Herrschaft," in Die Familie als historischer und sozialer Verband. Untersuchungen zum Spätmittelalter und zur frühen Neuzeit, ed. Peter-Johannes Schuler (Sigmaringen, 1987), pp. 204-309. See also: Olivier de Laborderie, "La mémoire des origines Normandes des rois d'Angleterre dans les généalogies en rouleau des XIII ${ }^{\text {e }}$ et XIV siècles," in La Normandie et l'Angleterre au Moyen Âge, Colloque de Crécy-la-Salle (4-7 octobre 2001), eds. Pierre Bouzet, and Véronique Gazeau (Caen, 2003), pp. 211-36; Olivier de Laborderie, Histoire, mémoire et pouvoir. Les généalogies en rouleau des rois d'Angleterre, 1250-1422 (Paris, 2013); John Spence,

(C) VINNI LUCHERINI, 2022 | DOI:10.1163/9789004511583_010

This is an open access chapter distributed under the terms of the CC BY-NC 4.o liçenşe. Lucherini - 9789004511583 Downloaded from Brill.come4/26/2023 03:20:11PM 
I am interested in is the isolated standing figure, characterized by one or more attributes or symbols of power. In this article, I intend to address how the Kingdom of Hungary contributed to this kind of iconography. I will examine a royally commissioned manuscript, along with some major European cases of royal galleries for comparison, and will propose new hypotheses not only about rhetorical strategies of representation but also about the supposed model for the Hungarian series.

Ms Budapest, Országos Széchényi Könyvtár, Cod. Lat. 404, frequently called in modern historiography the Hungarian Illuminated Chronicle or the Chronicon pictum, contains the oldest surviving representation of the whole history of the Hungarian kings, from its mythical Hun origins (the roots of which were traced back to the biblical story) to the reign of Charles I (r. 1310-1342). Charles was the eldest son of the Angevin prince Charles Martel, who in turn was the eldest son of Charles II of Anjou, rex Siciliae from 1289 to 1309, and Mary, the daughter of King Stephen V of Hungary (r. 1270-1272). ${ }^{3}$ The manuscript was

Reimagining History in Anglo-Norman Prose Chronicles (Woodbridge, 2013). From a general point of view: Christiane Klapisch-Zuber, L'ombre des ancêtres. Essai sur l'imaginaire médiéval de la parenté (Paris, 2000). On the relations between genealogical series and images: Andrew Martindale, Heroes, Ancestors, Relatives and the Birth of the Portrait. The Fourth Gerson Lecture, held in memory of Horst Gerson (1907-1978) in the aula of the University of Groningen on May 26, 1988 (Maarsen, 1988); Christian de Mérindol, "Portrait et généalogie: la genèse du portrait réaliste et individualisé," in Population et demographie au Moyen Âge, ed. Oliver Guyotjeannin (Paris, 1995), pp. 219-48; Catherine Léglu, "A Genealogy of the Kings of England in Papal Avignon: British Library, Egerton MS 1500," Electronic British Library Journal 18 (2013), http://www.bl.uk/eblj/2013articles/article18.html. Accessed 2020 April 15.

3 The literature on this manuscript is very rich, in Hungarian particularly. First of all, I suggest: The Hungarian Illuminated Chronicle, ed. Dezső Dercsényi (Budapest, 1969). Among the latest publications: László Veszprémi, Tünde Wehli, and József Hapák, The Book of the Illuminated Chronicle (Budapest, 20o9); Studies on the Illuminated Chronicle, eds. János M. Bak, and László Veszprémy (Budapest, 2018). See also: Vinni Lucherini, "Il Chronicon pictum ungherese (1358): racconto e immagini al servizio della costruzione dell'identità nazionale," Rivista di Storia della Miniatura 19 (2015), 58-72; Vinni Lucherini, "Le fonti antiche del Chronicon pictum ungherese (1358): narrare le origini della nazione e trasporle in immagini," Incidenza dell'antico 14/1 (2016), 61-88; Vinni Lucherini, "The Artistic Visualization of the Concept of Kingship in Angevin Hungary," in The Art of Medieval Hungary, eds. Xavier Barral i Altet, Pál Lővei, Vinni Lucherini, and Imre Takács (Rome, 2018), pp. 235-51; Vinni Lucherini, "The Hungarian Illuminated Chronicle (Pls. 44-47)," in The Art of Medieval Hungary, eds. Barral i Altet et al., pp. 409-12; Vinni Lucherini, La Cronaca angioina dei re d'Ungheria. Uno specchio eroico e fiabesco della sovranità (Paris, 2021). 
produced around the year 1358, as stated in the rubric of the incipit, and therefore during the reign of Louis the Great (r. 1342-1382), son and direct successor of Charles I (Figure. 8.1). The chronicle occupies 73 parchment folios in the codex, for a total of 146 pages: 54 pages present exclusively text, while 92 pages feature writing interrupted by one or more illuminations (103 initials and 43 miniatures, the latter within frames, some of which are decoratively patterned). More than $70 \%$ of the illuminations contain one of the following typologies: a. the figure of a king either seated, standing, or in action; b. a figure who is about to become king; c. a figure whom the concepteur or artist deemed appropriate to include in the visual sequence of Hungarian sovereigns. Let us begin by analysing the miniatures in which a king is represented.

Following the frontispiece (fol. $1 \mathrm{r}$ ), where King Louis the Great is seated in the traditional position of majesty, ${ }^{4}$ the first king shown is Attila, the protagonist of Hungary's prehistory (Figure. 8.2). ${ }^{5} \mathrm{He}$ is enthroned, with all the royal insignia (fol. $5 \mathrm{v}$ ). ${ }^{6}$ Twice thereafter he is represented as a half-length standing figure in oriental dress, ${ }^{7}$ with crown, sceptre, and orb (fol. 6r) or with a sabre instead of the sceptre (fol. $7 \mathrm{r}$ ); in one other miniature, he is a full-length figure in military dress, with crown, shield, and raised sword (fol. 7v). But the first 'real' king (primus rex Hungarorum) shown in the manuscript is Stephen, born in 969 according to the chronicler but, more likely, around 980-981; deceased on 15 August 1038; crowned in the year 1000; and canonized in 1083 by Pope Gregory VII, following the Hungarian tradition. ${ }^{8} \mathrm{He}$ is always represented with a halo, symbolizing his holiness. In the non-narrative initials, he is shown once

The maiestas iconography was common all over Europe, as for example in the pages of the Historia Anglorum of Matthew Paris (London, British Library, Royal MS 14 C VII, fol. 8v), where the kings are set into niches: Anthony Musson, "The Power of Images: Allusion and Intertextuality in Illuminated English Law Books," in Citation, Intertextuality and Memory in the Middle Ages and Renaissance. 1. Text, Music and Image from Machaut to Ariosto, eds. Yolanda Plumley, Stefano Jossa, and Giuliano Di Bacco (Exeter, 2011), pp. 113-26.

5 Among the vast bibliography, see: Edina Bozóky, Attila et les Huns. Vérités et legendes (Paris, 2012); Klaus Rosen, Attila. Der Schrecken der Welt (München, 2016).

6 On these insignia: Percy Ernst Schramm, Sphaira, Globus, Reichsapfel. Wanderung und Wandlung eines Herrschaftszeichens von Cäsar bis zu Elisabeth II. Ein Beitrag zum Nachleben der Antike (Stuttgart, 1958).

7 On the dress: Graf Istvan Zichy, "Die Miniaturen der Ungarischen Bilderchronik und die Kostümkunde," in Petrovics Elek emlékkönyv - Hommage à Alexis Petrovics (Budapest, 1934), pp. 59-70, 191-97; Stella M. Newton, "Tomaso da Modena, Simone Martini, Hungarians and St. Martin in Fourteenth Century Italy," Journal of Warburg and Courtauld Institutes 63 (1980), 234-38.

8 Marie-Madeleine de Cevins, Saint Étienne de Hongrie (Paris, 2004). For general accounts of the Kingdom of Hungary in the Middle Ages: Gyula Kristó, Histoire de la Hongrie médiévale. I. Le temps des Arpad (Rennes, 200o); Pál Engel, The Realm of St Stephen. A History of 
in isolation on a marble throne, with a red priestly dalmatic and all the royal insignia (fol. 2ov); in two instances, he is standing - in the first, he is young, in armour, and holds a flag and shield (fol. 2or); in the second (Figure. 8.4), he is older, with similar clothes and the regalia as well as a sword hanging from his belt (fol. 21r). Of the successors of Stephen, Peter Orseolo (r. 10381041 and 1044-1046), the son of Stephen's daughter and the Venetian doge Otto II Orseolo, ${ }^{9}$ and Aba (or Samuel Aba, r. 1041-1044), the husband of one of Stephen's sisters, each occupy their own initials, standing in military dress (without any heraldic signs), carrying the sword in their right hands and the crown in their left hands (fols. 24r-v).

Though the first mention of the royal regalia comes in the part of the text dedicated to Peter, ${ }^{10}$ Andrew I (r. 1046-106o) is the protagonist of the first coronation scene (fol. $30 \mathrm{v}$ ): he is enthroned in the middle of a great initial, clad in a long, blue, golden-striped robe, a sceptre in his left hand and a sword in his right (offered by a bishop), while two other bishops place the crown on his head, in the presence of a small crowd of people. ${ }^{11}$ The coronation of Solomon (r. 1063-1074), Andrew's son, is not represented but is visually alluded to on fol. $32 v^{12}$ The depiction of the coronation of Bela I (r. 106o-1063), Andrew's

Medieval Hungary 895-1526 (New York, 2001); Pál Engel, Gyula Kristó, and András Kubinyi, Histoire de la Hongrie médiévale 2. Des Angevins aux Habsbourg (Rennes, 2008).

9 In the Hungarian Illuminated Chronicle, Peter is said to be the brother of Stephen's wife, Gisela; in the older Deeds of the Hungarians, he is the son of Gisela's sister: Simon de Kéza, Gesta Hungarorum, eds. László Veszprémy, and Frank Schaer, with a study by Jenő Szűcs (Budapest, 1999), p. 16o. "Ibi [Alba, now Székesfehérvár] ergo Cesar [Emperor Henri III] imperiali honore et latissimo preparatu ab Ungaris honoratus Petrum regali corone plenarie restitutum et sacris insignibus sancti regis Stephani, more regio decoratum in regali throno manu sua deducens, in basilica gloriose genitrices Dei semper Virginis Mariae regaliter sedere facit" (Cod. Lat. 404, fol. 27r).

11 On Hungarian royal coronations, see: Dušan Zupka, Ritual and Symbolic Communication in Medieval Hungary Under the Árpád Dynasty, 1000-1301 (Leiden, 2016), pp. 35-49 (with previous bibliography).

The young Solomon, crowned, stands in a bedroom in which Andrew, still living, lies on a bed, while a layman touches the crown. The iconography of bedside coronation is particularly common in manuscripts containing the Histoire d'Outremer, such as Ms Paris, BnF, Français 9084, fol. 331r: Iris Gerlitz, “'The King is Dead, Long Live the King': Representing Transfer of Power in the Crusader Estoire de Eracles," in Between Jerusalem and Europe. Essays in Honour of Bianca Kühnel, eds. Renana Bartal, and Hanna Vorholt (Leiden, 2015), pp. 34-54; Svetlana I. Luchitskaya, "Ad succurrendum. Wie starben die Könige von Jerusalem?" Mediaevistik 22 (2009), 49-82; Svetlana I. Luchitskaya, "Pictorial Sources, Coronation Ritual, and Daily Life in the Kingdom of Jerusalem," in Ritual, Images, and Daily Life. The Medieval Perspective, ed. Gerhard Jaritz (Münster, 2012), pp. 49-74. Also relevant is Ms Paris, BnF, Français 1049, fol. 14v, which contains a similar iconography: Vinni 
brother, shows two laymen in sumptuous mantles lined with squirrel fur, ${ }^{13}$ transferring the crown from Solomon's head to Bela's (fol. 34r) and offering a sword. Within the initial R, Solomon, with all the insignia, and his brother David, with sword and shield, are represented isolated and standing, close to one another (fol. $36 \mathrm{r}$ ). Their positioning is almost the same as that of King Geza I (r. 1074-1077), who embraces the future saint Ladislaus (r. 1077-1095) ${ }^{14}$ in a historiated initial $\mathrm{P}$ (fol. 44r). After a solemn coronation celebrated by two bishops (fol. 46v), the crowned Ladislaus appears isolated and standing, wearing military clothes and holding a battle-ax (a symbol of chivalry and his typical attribute) and an orb (fol. 47r). The representation of his funeral, within a geometric frame, shares a page with the coronation of Coloman (r. 1095-1116), performed by one bishop in the presence of another (fol. $5^{11}$ ) as well as a crowd of people. His son, Stephen II (r. 1116-1131), is crowned in the act of walking (fol. 54V). Bela II the Blind (r. 1131-1141), the son of Duke Almos, is depicted standing in the initial $\mathrm{R}$, dressed in a long red mantle, with all the regalia (fol. $57 \mathrm{v})$. Geza II (r. 1141-1162), Bela II's son, is shown crowned and seated on a throne; his right hand takes a sword from a squire who holds the bridle of the white horse typical of Hungarian rulers (fol. 59r). He is also represented in the opposite column on the same page, standing crowned, with a sceptre in his left hand and a shield in his right (fol. 59r). In a historiated initial (fol. 6ov), he reappears in almost the same position (though with a sceptre and orb) while conversing with the French king Louis VII (r. 1137-118o). Geza II's son, Stephen III (r. 1162-1172), is, like his father, shown enthroned and crowned, as a man in oriental clothes and a high pointed and curved headdress offers him a long sword (fol. 6ir).

Lucherini, "The Journey of Charles I, King of Hungary, from Visegrád to Naples (1333): Its Political Implications and Artistic Consequences," The Hungarian Historical Review. New Series of Acta Historica Academiae Scientiarum Hungariae 2 (2013), 341-62. On the text of this Provencal planh, see: Anna Radaelli, "Tra finzione e realtà: la conplancha per Roberto d'Angiò, una voce per un re immaginato," Lecturae tropatorum 11 (2018), 1-69.

13 These are the same men present at the coronation of Solomon on fol. $32 \mathrm{v}$.

14 Ernö Marosi, "Der heilige Ladislaus als ungarischer Nationalheiliger. Bemerkungen zu seiner Ikonographie im 14.-15. Jh.," Acta historiae artium Hungariae 33 (1987), 232-34; Gábor Klaniczay, "L'image chevaleresque du saint roi au XII siècle," in La royauté sacrée dans le monde chrétien, Actes du colloque (Royaumont, mars 1989), eds. Alain Boureau, and Claudio-Sergio Ingerflom (Paris, 1992), pp. 53-61; Zsombor Jékely, "Narrative Structure of the Painted Cycle of a Hungarian Holy Ruler: The Legend of Saint Ladislas," Hortus artium medievalium 21 (2015), 62-74; Gábor Klaniczay, "San Ladislao d'Ungheria athleta patriae," in La lettera e lo spirito. Studi di cultura e vita religiosa (secc. XII-XV) per Edith Pásztor, eds. Marco Bartoli, Letizia Pellegrini, and Daniele Solvi (Milan, 2016), pp. 157-78. 
Each of the four initials on fols. 61v-62r contains a full-length, isolated king in a standing position. Stephen IV (r. 1163-1165), with a ducal headdress instead of a crown, takes only the sword (his reign was considered illegitimate); Bela III (r. 1172-1196), wears the crown and carries an orb and a flag with Arpadian stripes; the crowned Emeric (r. 1196-1204), son of Bela III, holds the sceptre and orb; Ladislaus (r. 1204-1205), son of Emeric (and here noted as secun$d u s$, though he was actually III, if we consider the $1162 / 63$ reign of Bela II's son, Ladislaus II), is shown with the same insignia. In the lower part of these pages, three little geometric frames enclose representations of the coronations of Emeric (seated on a frontal throne, two bishops crowning him); Ladislaus II (standing beside a throne); and Andrew II (r. 1205-1235), son of Bela III. Andrew II also occupies the following initial $\mathrm{H}$, where he is standing, holding the orb and a red flag (fol. 62v). His son, Bela IV (r. 1235-1270), seated on a throne, is crowned by two bishops (fol. 63r). He reappears, isolated and standing with full insignia, in the initial P (fol. 63v) and, again on the next folio (fol. $64 \mathrm{r}$ ), in the act of crowning his son, Stephen v (r. 1270-1272). In a large initial C, Ladislaus IV (r. 1272-129o), Stephan V's son, is represented in a standing position, clad in oriental garb, with a crown placed on a pointed headdress and with sceptre and orb (fol. 64v). The only one of his successors depicted in a standing position is Charles I (fol. 69v).

Despite the great care taken to differentiate the kings by age, hair colour, facial hair, and attire, for their physiognomical attributes the artist followed limited models. In some cases, he was influenced by what he read in the text or what somebody told him: Attila, who "color teter, oculis furiosus, elatu incessu, pectore lato, barbam prolixam defebat," is always depicted with a very thick beard; Coloman (Figure. 8.5), with long hair and a beard, has a humpback (fol. 51r), referring to one of the numerous defects listed by the chronicler ("ispidus, pilosus, luscus, gibosus, claudus et blesus"); Bela II has closed eyes to indicate his blindness (fol. $57 \mathrm{v}$ ). The interchangability of heraldic signs across the manuscript means that these cannot aid us in distinguishing one king from another, either..$^{15} \mathrm{~A}$ knight near Attila, in the battle scene on fol. ${ }_{5} \mathrm{r}$, carries a shield with the stripes of the Arpadian coat of arms (barry of eight gules and argent). In

15 On heraldic signs as vectors of social communication: Brigitte M. Bedos-Rezak, "Medieval Identity: A Sign and a Concept," in Medieval Coins and Seals: Constructing Identity, Signifying Power, ed. Susan Solway (Turnhout, 2015), pp. 23-63; as narrative forms: Xavier Barral i Altet, 'Forme di narrazione medievale, con o senza 'storie,' al servizio del potere," Hortus artium medievalium 21 (2015), 6-20. See also: L'individu au Moyen Âge. Individuation et individualisation avant la modernité, eds. Brigitte M. Bedos-Rezak, and Dominique Iogna-Prat (Paris, 2005). 
the first appearance of the young saint Stephen as a standing figure in an initial, he wears a tunic decorated with the Arpadian stripes, while his flag and shield feature an argent o-barred cross on a trimount. This cross can be seen on the tunic that Saint Stephen wears in the two great miniatures on fols. $20 \mathrm{v}$ and 21r, in the second initial that shows him in a standing position (fol. 21r), and on the tunic of Ladislaus, where the two-barred cross on the trimount is included in a rhombus (fol. 47r). Ladislaus holds a shield with the same rhombus as he fights Solomon, whose shield features Arpadian stripes (fol. 46r). The fallen flag with these stripes on fol. $25 \mathrm{v}$ refers to Aba's defeat in the Battle of Menfew, on 5 June 1044. Bela III holds a similar flag (fol. 6iv), and Andrew II holds a flag with the cross on the trimount (fol. 62v). All these examples speak to clear anachronisms and a substantial interchangeability among heraldry. ${ }^{16}$ Only Charles I and his son Louis the Great have heraldic signs that are individual (Figure. 8.6). Charles holds a shield combining the Arpadian coat of arms per pale on the heraldic right with the Angevin fleur-de-lys on the heraldic left (fol. 69v). In the depicted battle against Basarab of Wallachia, in which Charles was a protagonist, we note the ostrich crest emerging from a crown on the helmet of the knight who substitutes for the king (fol. 72r). ${ }^{17}$ Moreover, on the frontispiece of the manuscript, Louis - like Saint Stephen - wears a tunic decorated with Arpadian stripes. The same page includes a band on the basde-page with polylobate forms containing the Arpadian-Angevin coat of arms, the two-barred cross, and the helmet with the ostrich crest.

Louis is the only king who seems to show individualized facial features, though not in a manner comparable to the naturalistic portraits of Charles $\mathrm{V}$ of Valois (r. 1364-1380) or Charles IV of Luxembourg (king of Bohemia from 1347 to 1378 , emperor from 1355). This is because, in contrast to French and Bohemian artists of the same period, ${ }^{18}$ the artist responsible for the decoration

16 The so-called Arpadian shield has been documented since the time of Emeric (r. 11961204) and is interpreted as deriving from the Catalan coat of arms (i.e. four pallets of gules) through the marriage of Emeric to Constance, the daughter of King Alfonso the Chaste of Catalonia-Aragon: Szabolcs de Vajay, "L'héraldique image de la psychologie sociale," Atti dell'Accademia Pontaniana 16 (1967), 5-19, figs. I-XII. The two-barred cross appeared under Bela III (r. 1172-1196) but assumed a heraldic purpose under Bela IV (r. 1235-1270), probably before the Mongol invasion (1241/42): Takács, Az Árpád-házi királyok pecsétjei, pp. 120-23.

17 Christian de Mérindol, "L'héraldique des princes angevins," in Les princes angevins du XIII au $X V^{e}$ siècle: un destin européen, eds. Noël-Yves Tonnerre, and Élisabeth Verry (Rennes, 2004), pp. 277-307; György Rácz, "L'araldica dell'età angioina," in L'Ungheria angioina, ed. Enikő Csukovits (Rome, 2013), pp. 283-318, esp. 293-98.

18 Claire Richter Sherman, The Portraits of Charles Vof France (New York, 1969); Iva Rosario, Art and Propaganda. Charles IV of Bohemia, 1346-1378 (Woodbridge, 2000). 
of the Chronicon pictum did not have a figurative tradition to draw upon. Still, there are clear indications that this artist sought here to reproduce physiognomic elements. Joannes de Kikullew, in his biography of the king, speaks about his physical characteristics: "fuit homo competentis proceritatis, oculis elatis, crinibus et barba crispis, sereno vultu, labiosus, et aliquantulum in humeris curvus." ${ }^{19}$ Consistent with this description, in his portrait on the unfortunately damaged frontispiece, Louis in fact has enormous eyes, taking up much of his face, as well as dark, long, and thick hair. This is probably the only case in a Hungarian manuscript in which we can observe the process of so-called émergence de l'actualité. ${ }^{20}$

To summarize what we have observed so far, the chronicler speaks of 27 kings, excluding the living and ruling king, Louis the Great, who appears only on the frontispiece, and including Attila, two illegitimate kings (Ladislaus II, who is not represented, and Stephen IV), two kings from other dynasties (Wenceslaus of Bohemia, r. 1301-1305, and Otto of Bavaria, r. 1305-1307), ${ }^{21}$ and

19 Scriptores rerum Hungaricarum, ed. Joannes Georg Schwandtner (Tyrnaviae, 1765), p. 320. In quoting this passage, Friedrich Diez believed that a famous excerpt from De amore by Andrea Cappellano ("Rex est in Ungaria intensa plurimum habens crura sumulque rotunda prolixosque et aequales pedes et omnibus fere decoribus destitutus. Quia tamen nimia morum invenitur probitate fulgere, regalis coronae meruit accipere gloriam et per universum paene mundum resonant eius praeconia laudis") referred specifically to Louis the Great: Friedrich Diez, Beiträge zur Kenntniss der romantischen Poesie. Erstes Heft (Berlin, 1825), p. 81; French translation: Friedrich Diez, "Essais sur les Cours d'amour, traduit de l'allemand et annoté par M. le baron C. de Roisin," Mémoires de la Société royale des sciences, de l'agriculture et des arts de Lille (1841), 147-272. Historiography on this topic now tends to date the De amore to the end of the 12th century: Andreas aulae regiae capellanus/königlicher Hofkapellan, De amore libri tres/Von der Liebe drei Bücher, Text nach der Ausgabe von E. Trojel. Übersetzt und mit Anmerkungen und einem Nachwort versehen von Fritz Peter Knapp (Berlin 20o6). Among the vast bibliography, see especially: Alfred Karnein, De amore in volksprachlicher Literatur. Untersuchungen zur Andreas CapellanusRezeption in Mittelalter und Renaissance (Heidelberg, 1985).

20 The expression émergence de l'actualité is borrowed from: Roland Recht, "Le portrait et le principe de réalité dans la sculpture: Philippe le Bel et l'image royale," in Akten des XXV. Internationalen Kongresses für Kunstgeschichte 6, ed. Elisabeth Liskar (Vienna, 1986), pp. 189-201. He uses it mainly in relation to the initiatives of Philip IV and some of his contemporaries: “Par 'principe de réalité, ' j'entends, au Moyen Âge, la prise en compte du monde réel par celui de l'art. Le principe de réalité est aussi éloigné de l'idéalisation que du réalisme. ... Cette réalité peut aussi bien être celle des caractères physiques d'un individu que celle des signes par lesquels se manifeste un groupe social. Le principe de réalité est nécessairement un principe d'individuation: il s'agit, à l'aide des formes artistiques, de rendre compte des différences."

21 Wenceslaus and Otto - like Andrew III (r. 1290-1301), who was traditionally considered the last member of the Arpadian line - are represented only in narrative scenes yet never 
one king who was born not in Hungary but in Naples, namely Charles I. Almost every king is portrayed more than once. ${ }^{22}$ The standing, isolated kings occupy the internal space of 23 initials, as if in a niche separating them from the continuous development of the historical tale. They always stand - and sometimes rest their shields, where applicable - on a rocky platform, ${ }^{23}$ which serves the same function as a statue's pedestal. Moreover, they do absolutely nothing: like statues, they are motionless.

The question is: where else in Europe can we find these galleries of standing kings, which are so characteristic of the Chronicon pictum that they become one of its most distinctive signs of authority? If we compare this to other contemporary illuminated chronicles, such as the Grandes chroniques de France, ${ }^{24}$ we detect a significant difference. For example, in Ms Paris, BnF, Français 2813, which was illuminated for King Charles v, "an authoritative manuscript influencing a generation of royal and courtly books," ${ }^{25}$ all the kings are doing something. If they are still, whether while seated or standing, they always take part in an action or ceremonial event. Only Charlemagne, on fol. 103v, is seated alone in the maiestas position, holding the emblems of his office - assuming the model of the biblical king common in medieval Europe within the corpus

standing or with royal attributes, because the members of the Angevin dynasty who commissioned the codex did not consider them legitimate kings.

In the whole manuscript, only Stephen's father, the duke Geza, is represented with sceptre and orb, but without the crown (Cod. Lat. 404, fol. 19v).

23 The rock formation that acts as a pedestal clearly takes Giotto as a model. On the figurative culture of the artist: Ernö Marosi, Kép és hasonmás. Müvészet és valóság a 14.-15. századi Magyarországon [Image and Likeness: Art and Reality in the 14th and 15th Centuries in Hungary] (Budapest, 1995); Ernö Marosi, "The Illuminations of the Chronicle," in Studies on the Illuminated Chronicle, eds. Bak et al., pp. 25-110.

24 Anne D. Hedeman, The Royal Image. Illustrations of the Grandes Chroniques de France 1274-1422 (Berkeley, 1991); Anne D. Hedeman, "Presenting the Past: Visual Translation in Thirteenth- to Fifteenth-Century France," in Imagining the Past in France. History in Manuscript Painting 1250-1500, eds. Elizabet Morrison, and Anne D. Hedeman (Los Angeles, 2010), pp. 69-88. On the redactions: Bernard Guenée, "Les Grandes Chroniques de France, le roman aux roys (1274-1518)," in Les Lieux de mémoire 2. La Nation, ed. Pierre Nora (Paris, 1986), pp. 189-214. On the historiographical context: Gabrielle M. Spiegel, "The Reditus Regni ad Stirpem Karoli Magni: A New Look," French Historical Studies 7 (1971), 145-74.

25 Hedeman, The Royal Image, p. 95. The manuscript dated to three different moments of the reign of Charles v: before 1375, before 1377, and after 1378 . 
of royal seals. ${ }^{26}$ Moreover, in the edition of the Grandes chroniques commissioned by the future John II, before he assumed the throne in 1350 (London, British Library, Royal MS 16 G. VI), ${ }^{27}$ fol. 3 r contains, at the top of the page, a two-column table illustrating the coronation of Pharamond, the mythical first king of France. He is flanked by a man with long brown hair and a beard, dressed in the same mantle as him (his father Marcomir, Duke of Sicambria?), and two crowned old kings, with white hair and beards, wrapped in cloaks covered in fleurs-de-lys: the three figures are all on pedestals, like statues. We can take other genres of writing into consideration as well, like the several manuscripts illustrating the Arbor genealogiae regum by the friar preacher Bernard Gui (126o-1331). In the Cambridge copy (Trinity College, MS R.4.23, fols. $49 \mathrm{v}-57 \mathrm{r}$ ), the first geometrical illumination shows two seated men conversing (Turchotus or Thorgotus and Francio, predecessors of the Sicambri). Along with brief information about the names and reigns of the French kings - from Pharamond to Louis $\mathrm{x}$, the eldest son of Philip IV - the subsequent pages contain medallions in which the kings are represented in full length, wearing blue robes patterned with gold fleurs-de-lys and holding fleurs-de-lys sceptres. ${ }^{28}$

26 See, for example, the French case: Marjolaine Caucheteux-Chavannes, Les sceaux des rois de France d'Hugues Capet à François I I "Échanges d'influences dans les chancelleries souveraines du Moyen Âge, d'après les types de sceaux de majesté," in Académie des inscriptions et belles-lettres, Comptes-rendus des séances de l'année 1968 (Paris, 1968), 192-200; Martine Dalas-Garrigues, "Le premier sceau de substitution de Charles V," Bibliothèque de l'École des chartes 144/2 (1986), 355-59; Martine Dalas-Garrigues, Corpus des sceaux français du Moyen Âge 2. Les sceaux des rois et de régence (Paris, 1991). On Hungarian seals: Imre Takács, Az Árpád-házi királyok pecsétjei [Royal Seals of the Arpad Dynasty] (Budapest, 2012); Ernö Marosi, "Die drei Majestätssiegel König Karl Roberts von Ungarn," in Akten des XXV. Internationalen Kongresses für Kunstgeschichte (Wien, 4.-10. September 1983), eds. Hermann Fillitz, and Martina Pippal, 9 vols. (Wien, 1984-1986), 6 Europäische Kunst um 1300 (Wien, 1986), pp. 249-56.

27 Hedeman, The Royal Image, pp. 213-20; Anne D. Hedeman, "Constructing Saint Louis in John the Good's Grandes Chroniques de France (Royal MS 16 G. VI)," Electronic British Library Journal 19 (2014), http://www.bl.uk/eblj/2014articles/article1o.html. Accessed 2020 April 15 .

28 Anne-Marie Lamarrigue, "La rédaction d'un catalogue des rois de France. Guillaume de Nangis et Bernard Gui," in Saint-Denis et la Royauté, eds. Françoise Autrand, Claude Gauvard, and Jean-Marie Moeglin (Paris, 1999), pp. 481-92. On the manuscripts: Léopold Delisle, "Notice sur les manuscrits de Bernard Gui," Notices et extraits des manuscrits de la Bibliothèque nationale et autres bibliothèques 27/2 (1879), 245-52; Sheila Strongman, "John Parker's Manuscripts: an Edition of the Lists in Lambeth Palace MS 737," Transactions of the Cambridge Bibliographical Society 7 (1977-80), 1-27. 
There is no doubt that the iconography of the isolated standing king, whether alone or in a series, was specially cultivated by French artists, and above all sculptors, at the time of Philip IV (r. 1285-1314). ${ }^{29}$ Two drawings from the famous collection of François Roger de Gaignières show the statue of Louis IX of France placed "à droite au-dessus du jubé des religieuses" of Saint-Louis de Poissy and, "à gauche," the statue of Marguerite de Provence. Other drawings reproduce the statues of Louis IX's six children, standing on consoles inside niches along the back wall of the transept's left arm. ${ }^{30}$ Statues of Philip IV and his wife Jeanne de Navarre were situated at the entrance of the Collegium Navarrae and on the façade of the interior chapel; ${ }^{31}$ a statue of the same king, with his counsellor Enguerran de Marigny by his side, stood on the trumeau at the entrance of the renovated Palais de la Cité. In this context, we cannot forget one of the most renowned examples of public royal genealogy, which also included standing figures: the statuary complex of the Grand'salle in the same Parisian palace. The polychrome statues of France's kings, again starting with Pharamond, were set over the piers in the middle of the hall and along its two long walls. ${ }^{32}$ The inscriptions over the plinth named the kings and their fathers

29 Elizabeth A. R. Brown, "Philip the Fair and His Family: His Sons, Their Marriages, and Their Wives," Medieval Prosopography 32 (2017), 125-85. For the general context, see: The Capetian Century 1214 to 1314, eds. William Chester Jordan, and Jenna Rebecca Philipps (Turnhout, 2017).

30 On these drawings: Alain Erlande-Brandenburg, "La priorale Saint-Louis de Poissy," Bulletin Monumental 129/2 (1971), 85-112, esp. figs. 8-10.

31 Michael T. Davis, "The Architecture of the Collège of Navarre in Paris," in Medieval Women and Their Objects, eds. Jenny Adams, and Nancy Mason Bradbury (Ann Arbor, 2017), pp. 71-96. See also: Dorothy Gilllerman, Enguerran de Marigny and the Church of NotreDame at Ecouis. Art and Patronage in the Reign of Philip the Fair (University Park, 1994); along with the reviews: Nicola Coldstream in Speculum 71/4 (1996), 949-51; Dany Sandron in Bulletin monumental 154/2 (1996), 184-87.

32 Noël Valois, "Les statues de la grande salle du Palais," Bulletin de la Société de l'histoire de Paris et de l'Île de France 3o/1 (1903), 87-90; Jean Guérout, "Le Palais de la Cité à Paris des origines à 1417. Essai topographique et archéologique," Mémoires de la Féderation des Sociétés historiques et archéologiques de Paris et de l'Île-de-France 1 (1949), 57-212; 2 (1950), 21-204; 3 (1951), 7-101. The most pertinent study of this sculptural complex, destroyed by fire in 1618, is still: Uwe Bennert, "Art et propagande politique sous Philippe IV le Bel: le cycle des rois de France dans la Grand'salle du palais de la Cité," Revue de l'art 97 (1992), 4659. See also: Bernd Carqué, "Non erat homo, nec bestia, sed imago. Vollplastische Bildwerke am Hof Philipps IV. von Frankreich und die Medialität der Gattung," in Bilder der Macht in Mittelalter und Neuzeit. Byzanz, Okzident, Russland, eds. Otto Gerhard Oexle, and Michail A. Bojcov (Göttingen, 2007), pp. 187-242; Michael Davis, "Désespoir, Espérance, and Douce France: The New Palace, Paris, and the Royal State," in Fauvel Studies. Allegory, Chronicle, Music and Image in Paris, Bibliothèque Nationale de France, MS Français 146, eds. Margaret Bent, and Andrew Wathey (Oxford, 1998), pp. 187-213. On the modifications 
and gave the dates of their reigns and their deaths. ${ }^{33} \mathrm{~A}$ similar emphasis on dynastic succession can be found in other sculpted royal images, i.e. those on the so-called Montjoies (monuments topped with a cross and decorated with statues of kings); ${ }^{34}$ the galleries of kings on cathedral façades; ${ }^{35}$ and the royal tombs at Saint-Denis. ${ }^{36}$

of the genealogical lists in the Grandes chroniques de France: Isabelle Guyot-Bachy, and Jean-Marie Moeglin, "Comment ont été continuées les Grandes Chroniques de France dans la première moitié du XIVe siècle," Bibliothèque de l'École des chartes 163/2 (2005), 385-433. Again, on Philip IV's strong interest in images: Perkinson, The Likeness of the King, pp. 121-28.

33 The impression this gallery made on the spectator is documented in the words of Jean de Jandun, in his Tractatus de laudibus Parisius ("Pro inclite vero recordationis honore, ydola cunctorum regum Francie, qui hactenus precesserunt, sunt ibidem adeo perfecte representationis proprietate formata, ut primitius inscipiens ipsa fere iudicet quasi viva sunt"): Jean de Jandun, "Éloge de Paris," in Paris et ses historiens aux $X I V^{e}$ et $X V^{e}$ siècles. Documents et écrits originaux, eds. Antoine Jean Victor Leroux de Lincy, and Lazare-Maurice Tisserand (Paris, 1867), p. 48. For an English translation, see: Hedeman, The Royal Image, p. 35 ("For the honour of their glorious memory, the statues of all the Kings of France who occupied the throne up to the present are gathered in this place. Their likeness is so expressive that at first glimpse one would believe they were alive").

34 Anne Lombard-Jourdan, "Montjoies and Montjoie dans la plaine Saint-Denis," Mémoires de la Fédération des sociétés historiques et archéologiques de Paris et de l'Ile-de-France 25 (1974), 141-81.

35 During the 13th century, four French cathedrals - Paris, Chartres, Reims, and Amiens featured one or more galleries of sculpted kings, sometimes identified with the French kings: Claudine Lautier, "Les deux galeries des rois de la cathédrale de Chartres," Bulletin monumental 169 (2011), 41-64. See also: Johann Georg Prinz von Hohenzollern, Die Königsgalerie der französischen Kathedrale. Herkunft, Bedeutung, Nachfolge (Munich, 1965); Gerhard Schmidt, "Bemerkungen zur Königsgalerie der Kathedrale von Reims," Wiener Jahrbuch für Kunstgeschichte 25 (1972), 96-106; Jean Villette, "Les galeries des rois aux façades des cathédrales. Rois de France ou rois de Juda?," Mémoires de la Société Archéologique d'Eure-et-Loir 31/4 (1991), 143-68.

36 The connection between these artistic works is always stressed in the literature, especially in the research of the last decades: Joan A. Holladay, "Kings, Notaries, and Merchants. Audience and Image in the Grand'salle of the Palace at Paris," in Ritual, Images, and Daily Life. The Medieval Perspective, ed. Gerhard Jaritz (Münster, 2012) pp. 75-94; Joan A. Holladay, Genealogy and the Politics of Representation in the High and Late Middle Ages (Cambridge, 2019). Holladay thinks the model of the Grand'salle must be recognized in the series of papal portraits in Saint Peter and Saint Paul in Rome. See also: Anja Rathmann-Lutz, Images Ludwigs des Heiligen im Kontext dynastischer Konflikte des 14. und 15. Jahrhunderts (Berlin, 2010), esp. pp. 75-77. On the statues in the Palais des comtes de Poitou: Diane Joy, “Un manifeste politique des Valois: le programme statuaire du palais de Poitiers sous Jean de Berry," in Regards croisés sur le monument medieval. Mélanges offerts à Claude Andrault-Schmitt, ed. Marcello Angheben (Turnhout, 2018), pp. 431-44. 
We do not know exactly how the French 'obsession' with effigies of kings acted as a model outside of France, or even if other dynasties stressed their roots in a parallel way. However, I can mention at least one large royal artistic commission, made for the Royal Palace in Barcelona soon after the Parisian sculptural decorations, yet lesser known. On 20 September 1342, King Peter III of Catalonia-Aragón (r. 1336-1387), called the Ceremonious, writing to the general mayor of Catalonia, spoke about 19 "ymages" made of alabaster, which he had commissioned to the sculptor "Aloy," ${ }^{37}$ eight of which were to represent "effigies octo regum qui fuerunt unus post alium successivae usque ad nostra tempora reges Aragonum et Barchinone comites inclusivae" and the other 11 "qui fuerunt tum comites Barchinonae, titulum regium non habentes." ${ }^{38} \mathrm{On}$ 17 July 1350, the same king ordered that all the statues ("regum et comitum effigies sive statuas") made by "magister Aloy" in Girona, which we can presume were standing figures, be brought to Barcelona by sea. ${ }^{39} \mathrm{On} 20$ October 1351, the king ordered his procurators in Roussillon and Cerdanya to send to Perpignan "quondam ymaginem lapideam ad similitudinem nostri facta quae

37 On this artist: Emma Liaño Martínez, "Aloy de Montbray imaginator. Del Reino de Francia a la Corona d'Aragón en le siglo XIV," Locus Amøenus 12 (2013-14), 29-53 (with bibliography).

38 Antoni Rubió i Lluch, Documents per l'història de la cultura catalana mig-eval, 2 vols (Barcelona, 1908-1921), 1, pp. 124-25 (Arxiu de la Corona d'Aragó, reg. 1305, fol. 92v). The same earls and kings decorated a sword that Peter III had ordered on 28 February 136o: "Fem vos saber que nos trametem an Berenguer de Codinachs, maestre racional de la nostra cort, dc florins $\mathrm{d}$ or convertidors en guarniment de una espasa la qual se coronen los nostres succeïdors reys d Arago, lo qual guarniment an Pere Bernes, argenter nostre, que faça ab vostre Consell, perque us dehim e us manam que l dit guarniment façats fer com pus bell e pus rich e pus subtil porets, e aço comanam tot a vostra discreció. Mas en special volem que en la behina a de fora haia de $\mathrm{l}$ un cap al altre xix esmalts qui sien en manera fets que en cascu puxa esser feta una figura de rey o de comte. car nos en los dits esmalts volem fer fer les figures dels reys d Arago e comtes de Barchinona passats e la nostra" (Rubió i Lluch, Documents 1, pp. 153-54: Arxiu de la Corona d'Aragó, reg. 1318, fol. 99). Particularly interesting is the letter that the same king wrote from Barcelona to the abbot of Ripoll on 2 September 1358: "Com nos per alcunes rahons haiam mester informacio en quina manera e forma som figurats e pintats tots los comtes de Barchinona qui jahen en lo monastir de Ripoll, ço es en quina edat es figurat e en quina forma e de quina color portave cascu los cabells del cap e de la barba, e si portava garceta, e en quina manera es vestit cascun de mantells e de cotes e d alters vestedures, e si tenen o porten res en lo cap, e que te cascun en cascuna man, e cascun comte fets scriure per son nom e apres fets be scriure la sua figura en la forma damunt dita, e aquesta informacio nos tremetets encontinent per lo portador de la present" (Rubió i Lluch, Documents 1, p. 185: Arxiu de la Corona d'Aragò, reg. 116o, fol. 122v).

Rubió i Lluch, Documents 1, pp. 191-92 (Arxiu de la Corona d'Aragó, reg. 1170, fol. 25). 
est in villa Castilionis Impuriarum." ${ }^{40}$ In this Catalan example, the patronage of a sculpted genealogy - with Peter the Ceremonious deciding, on 3 September 1370, on the design of the tomb and sculptures for his ancestors James I and Alfonso $^{41}$ - is accompanied by a rearrangement of ancient royal tombs as well as by a very strong interest in both national and foreign historical chronicles. ${ }^{42}$

40 Rubió i Lluch, Documents 1, pp. 156-57 (Arxiu de la Corona d'Aragó, reg. 1320, fol. 9ov). Wooden images covered by wax were painted "a semblança del sinyor rey" or of the Queen Eleonor, then included in tabernacles of painted wood: Rubió i Lluch, Documents 2, p. 125 .

41 This is the will of the king: "primerament lo dit Jacme [de Castalls] es tengut a fer e obrar dues ymages de pedra a estatura del rey en Jacme besavi del senyor rey, qui conqueri los regnes de Mallorques e de Valencia de mans de infels, ço es una a figura e a manera de rey coronat en la una part del seu vas, e altra a figura e manera de monge ab son abit vestit e qui jau tinent corona reyal en son cap en $\mathrm{l}$ altre part del dit vas posadora. E que aquella ymage del dit rey en Jacme, la qual lo dit Maestre havia ja feta e devia acabar per vigor de una altra covinença feta ab lo senyor rey o ab l abat de Poblet per nom seu, devia posar en una parte del vas del senyor rey n Amfos, fill den Ramon Berenguer, comte de Barchinona e princep d Arago, ultra altra ymage la qual aqui havia de posar per rao de covinença feta per lo senyor rey e per lo dit abat en nom seu. E volch e mana lo senyor rey que lo vas o tomba del dit rey en Jacme sobrepuys e sia egualada al vas o sepultura la qual lo senyor rey ha fet fer e construir per lo dit maestre en lo dit monestir de Poblet per lo seu cors e de las senyores reynes mullers sues, per rao de la qual cosa, ultra les obres les quals ja son aqui fetes e son faedores per lo dit mestre per rao de la dita covinença, son necessaris x. senyals reyals esmaltats e daurats e altres obres, segons que a la dita obra se pertany": Rubió i Lluch, Documents 1, pp. 226-28 (Arxiu de la Corona d'Aragó, reg. 1084, fol. 108). On genealogical series in the Kingdom of Catalonia-Aragón: Amadeo Serra Desfilis, "La historia de la dinastía en imágenes: Martín el Humano y el rollo genealógico de la Corona de Aragón," Locus Amøenus 6 (2002-03), 58-74. On Poblet's tombs: Bruno Klein, "Comment parler des arts au XIV ${ }^{\mathrm{e}}$ siècle? La genèse du panthéon aragonais-catalan à Pöblet à l'époque du roi Pierre le Cérémonieux," in Visualisierung und kultureller Transfer, eds. Kirstin Kramer, and Jens Baumgarten (Würzburg, 2009), pp. 83-10o.

Ferran Soldevila, Les quatre grans cròniques, ed. Josep Massot i Muntaner (revisió filològica de Jordi Brugera, revisió històrica de Maria Teresa Ferrer i Mallol): 1. Llibre dels feits del re en Jaume (Barcelona, 2007), 2. Crònica de Bernat Desclot (Barcelona, 2008), 3. Crònica de Ramon Muntaner (Barcelona, 2011), 4. Crònica de Pere III el Cerimoniòs (Barcelona, 2014), 5. Apèndix $i$ index (Barcelona 2016), with an essay by Maria Teresa Ferrer i Mallol, "Les quatre grans Cròniques: una visió de conjunt," 13-73. See also: Stefano Maria Cingolani, Historiografia, propaganda i comunicació al segle XIII: Bernat Desclot $i$ les dues redaccions de la seva Crònica (Barcelona, 2006); Jaume Aurell, Authoring the Past. History, Autobiography and Politics in Medieval Catalonia (Chicago, 2012). On the relationship between propaganda and royal discourse: Suzanne F. Cawsey, Kingship and Propaganda. Royal Eloquence and the Crown of Aragon c. 1200-1450 (Oxford, 2002). Among the several documents concerning the purchasing, writing, or illustrating of chronicles, I might just mention one extremely meaningful letter, sent on 28 September 1370, in which King Peter III ordered Berenguer d'Abella (his counsellor, who in 1369 was part of the Catalan embassy in Paris to manage the frustrated marriage of John to Jeanne de 
Likely more directly linked to the French tradition of royal representation was the genealogical decoration of the royal palace of Karlštejn, undertaken by Charles IV of Luxembourg, who had surely visited the Grand'salle when he met Charles V (r. 1364-1380) in Paris. ${ }^{43}$ As documented in a later textual source, namely a chronicle by Edmund Dynter, ambassador of Brabante to the court of Wenceslaus IV in 1413, Bohemian genealogy was depicted on the walls:

Meque postea per manum capiens, duxit in quandam aulam, in qua preciosae imagines omnium ducum Brabanciae usque ad ducem Johannem Brabanciae huius nominis tercium inclusivae sunt depictae, quas praedictus Karolus imperator genitor suus inibi depingi fecerat, [Wenceslaus] dixitque ad me quod illa sua esset genealogia quodque ipse de propagine Troianorum et signanter sancti Karoli magni imperatoris et inclitae domus Brabanciae descendit, et quod Heinricus de Lucemburgo imperator, proavus suus, habuit filiam primi ducis Johannis Brabanciae, ex qua genuit avum suum Johannem Bohemiae et Poloniae regem. ${ }^{44}$

When we compare the Bohemian, French, and Catalan examples to the Chronicon pictum, it becomes clear that the gallery of Hungarian kings in the manuscript was designed to create the perception of an uninterrupted temporal sequence: starting with Attila, King of the Huns; moving on to Stephen, the first king of Hungary; and reaching its historical climax with both Charles I, whose works close the manuscript, and his son Louis, whose effigy dominates the frontispiece.

Valois) to procure him in Paris the books "de croniques dels reys d Ongria, de Dacia, de Norega o alters venien a vostra ma": Rubió i Lluch, Documents 1, pp. 229-30 (Arxiu de la Corona d'Aragó, reg. I.230, fol. 40v).

43 František Šmahel, The Parisian Summit, 1377-78. Emperor Charles IV and King Charles Vof France (Prague, 2014).

44 Chronique d'Edmund Dynter 3 (Bruxelles, 1857), p. 74; Karel Stejskal, "Die Rekonstruktion des Luxemburger Stammbaums auf Karlstein,” Umëni 26 (1978), 535-63. On Charles IV and his cultural policy: Karel Stejskal, L'Empereur Charles IV: l'art en Europe au XIVe siècle (Paris, 1980); Prague. The Crown of Bohemia 1347-1437, eds. Barbara Drake Boehm, and Jiř́ Fajt (New York, 2005); Karl IV. Kaiser von Gottes Gnaden. Kunst und Repräsentation des Hauses Luxemburg 1310-1437, ed. Jiř́ Fajt (Prague, 2006); Kunst als Herrschaftsinstrument. Böhmen und das Heilige Römische Reich unter den Luxemburgern im europäischen Kontext, eds. Jiří Fajt, and Andrea Langer (Berlin, 2oog); Robert Suckale, "Zur Ikonografie der deutschen Herrscher des 14. Jahrhunderts. Rudolf I. - Ludwig IV. - Karl IV.," in Die Goldene Bulle. Politik, Wahrnehmung, Rezeption, eds. Ulrike Hohensee, Mathias Lawo, Olaf B. Rader, and Michael Lindner (Berlin, 20o9), pp. 327-48. 


\section{$3 \quad$ Portraits or Royal Symbols?}

The Chronicon pictum appears to be a genealogical system of representation in which only regalia, coats of arms, and sometimes ceremonial robes allow us to distinguish a king from a knight. This choice on the part of the illuminator - or of the concepteur of the manuscript's decorative programme, who may well not have been the same person - is evidenced by another element: 23 initials contain depictions of knights that, in format, closely resemble the kings, all being modelled on a common prototype (Figure. 8.3). The knights are shown either in isolation or in a group; they stand on rock formations and wear military garb, including helmets or rounded headdresses, shields, and swords. The fact that the knights make up a visual gallery of standing figures, parallel to that of the kings in the same manuscript, demonstrates that the miniaturist felt authorized to apply to the members of the aristocracy the same iconography he had used for the kings. ${ }^{45}$ The chronicle text itself describes knights as members of families from outside Pannonia, whose descendants, or those who claimed to be such, formed the basis for the Hungarian nobility. ${ }^{46}$

45 These figures probably correspond to Eleud and his son Almus (fol. 11r), certainly to the seven captains from Scythia (Arpad, Zoboleh, Gyula, Cund, Leel, Werbulchu, and Vrs, represented all together as well as in individual initials: fols. 12r-v, 13r-13v), to the foreign founders of the ten influential families of the kingdom (generatio Tata, generatio filiorum Hedrih, generatio Vecellini, generatio Hunt et Paznan, generatio Poth, generatio Oliverii et Ratoldi, generatio Hermani de Alamania, generatio Buzad, generatio Keled, and generatio de Symone et Michaele: fols. 14v-15r-v, 16r), to the foreign groups of people that would acquire the same rights of nobility and residence as the others (fol. $16 \mathrm{v}$ ), and finally to the duke Toxun (fol. 17r). To these we must also add the figure of Geza, father of Stephen (fol. 18v). The narration of the second entrance of the ancestors of the Hungarian kings from Scythia to Pannonia, after Attila, in the Chronicon pictum partially coincides with the account given in the Gesta Hungarorum by Simon de Kéza. Simon, after dedicating a long description to the figure of Attila and his descendants, recorded how, once they had reached Pannonia in 872 , the Huns divided into seven armies, each of which had a captain for a total of more than 30,000 men, and dedicated the final part of his account to listing the noble families from abroad: Simonis de Kéza, Gesta Hungarorum. Simon of Kéza, The Deeds of the Hungarians, ed. László Veszprémy, and Frank Schaer, with a Study of Jenő Szűcs (Budapest, 1999), pp. 80-87, 158-75. In the Chronicon pictum, these two blocks of text are side by side and differ in several ways from Simon's text.

46 On the Hungarian aristocracy: Erik Fügedi, "The Aristocracy in Medieval Hungary," in Kings, Bishops, Nobles and Burghers in Medieval Hungary, ed. János M. Bak (London, 1986), pp. 1-14; Martyn C. Rady, Nobility, Land and Service in Medieval Hungary (London, 2000). On the culture of this social class: László Veszprémy, "The Knightly Culture of the Hungarian Barons of the Angevin Period: Ideals and Practice," in Formations et cultures des officiers et de l'entourage des princes dans les territoires angevins (milieu XIII ${ }^{-}$-fin XV siècle), eds. Isabelle Mathieu, and Jean-Michel Matz (Rome, 2019), pp. 297-314. 
The question I would like to pose is this: how can we explain the iconography of series of isolated, almost iconic, standing figures, and, given that this iconography was so uncommon in contemporary illuminated chronicles, what other artistic media might it have come from? I will put forward some hypotheses here. It is well known that - in many medieval Hungarian churches, especially those located in territories of the Kingdom of Hungary that now belong to other nations - there are still some wall paintings representing the socalled sancti reges Hungariae or "Hungarian saint-kings," namely Stephen and Ladislaus, along with Emeric, though he was in fact never king. ${ }^{47}$ In the final years of Charles I's reign, under Louis the Great and Sigismund of Luxembourg (r. 1387-1437), many sacred buildings were decorated with paintings, including this theme: in almost all the surviving cases, the saints are represented frontally and in a standing position. ${ }^{48}$ Louis also promoted the cult of these holy kings by founding a chapel in the Aachen Cathedral. The famous great mantle clasps from this chapel (now in the treasury) feature three tabernacles at the top, occupied by these figures. ${ }^{49}$

Might the iconography of the saint-king, enclosed in a niche or under a Gothic baldachin, be a model for the standing, isolated king of the Chronicon pictum? Can we imagine the artist taking inspiration from a painted image of Saint Stephen and projecting that iconography onto other kings, even those

47 Gábor Klaniczay, "Rois saints et les Anjou de Hongrie," Alba Regia 12 (1985), 57-66; Gábor Klaniczay, "Le culte des saints dynastiques en Europe centrale (Angevins et Luxembourg au XIV e siècle)," in L'Église et le peuple chrétien dans les pays de l'Europe du centre-est et du nord, XIVe-XVe siècles (Rome, 199o), pp. 221-47; Gábor Klaniczay, "La noblesse et le culte des saints dynastiques sous les rois angevins," in La noblesse dans les territoires angevins à la fin du Moyen Âge, eds. Noël Coulet, and Jean-Marie Matz (Rome, 200o), pp. 511-26; Gábor Klaniczay, Holy Rulers and Blessed Princesses. Dynastic Cults in Medieval Central Europe (Cambridge, 2002).

48 See: Dragoș-Gheorghe Năstăsoiu, Between Personal Devotion and Political Propaganda: Iconographic Aspects in the Representation of the sancti reges Hungariae in Church Mural Painting (14th Century - Early 16th Century), PhD, Central European University of Budapest (Budapest, 2018). On the only surviving royal genealogical cycle painted in a church: Zsombor Jékely, "A magyar királyok genealógiai ciklusa a leleszi premontrei kolostorkápolna középkori falképein [Genealogical Cycle of Hungarian Kings on the Medieval Frescoes at the Premonstratensian Abbey of Lelesz (Leles, Slovakia)]," Müvészettörténeti Értesítő [Bulletin of Art History] 61 (2012), 175-86. He recognizes the model in the Grandes chroniques de France, especially in the Brussels manuscript, Bibliothèque Royale, 5 , fol. 1 .

49 Imre Takács, "Deux joyaux armoriés," in Sigismund rex et imperator. Art et culture à l'époque de Sigismond de Luxembourg 1387-1437, exhibition catalogue, ed. Imre Takács (Budapest, 2006), pp. 101-02; Imre Takács, "L'art de la cour royale à la fin de l'époque angevine," in Sigismund rex et imperator, ed. Takács, pp. 68-86. 
who were not saints? The comparison is tempting. ${ }^{50}$ In medieval Hungarian imagery, Saint Stephen was the perfect model for royal behaviour, and Saint Ladislaus was identified with the athleta patriae. ${ }^{51} \mathrm{~A}$ saintly forefather would certainly confer his sanctity to all his successors, thus sacralizing Hungarian monarchic power. And yet, my impression is that this is not the only explanation, because the Chronicon pictum appears to be an eminently chivalric object. While the representations of Stephen and Ladislaus standing in military garb may call to mind the wall paintings of the santi reges Hungariae, dynastic sanctity does not play a particularly important role in its programme of illuminations. Even Emeric appears only once, namely at his burial, a narrative scene that also shows violence perpetrated against a member of the family, Vazul (fol. 22v).

I wonder, then, if we can suspect the existence of genealogical paintings on the walls of Hungarian royal residences. This is a little-studied topic, mainly due to the almost total absence of material or textual documentation. But some clues might lead us to imagine that one or more Hungarian sovereigns acted not so differently from their Bohemian counterpart Charles IV of Luxembourg. One of the rooms in the castle of Vajdahunyad in south-west

50 Presumably, several models intervened in the process of the construction of the single, isolated figures. Scholars have recognized older Hungarian models in some of the kings portrayed in the Chronicon pictum. For example: Joseph Polzer, "Lultimo dipinto di Simone Martini," Antichità viva 19/6 (1980), 7-16, argued that figures such as Ladislaus on fol. $47 \mathrm{r}$ might have had the same model as those in the San Ladislao panel by Simone Martini, now at Altomonte; on this painting, see: Sarah K. Kozlowsli, "Panel Painting Between the Courts of Naples and Hungary. A Hypothesis for Simone Martini's Saint Ladislaus and a Painting of Christ on the Cross," Convivium 6 (2020), 79-97. Polzer compared the clothes and the position of the Altomonte figure with Hungarian coins showing a standing Ladislaus. Ernö Marosi, "Saints at Home and Abroad. Some Observations on the Creation of Iconographic Types in Hungary in the Fourteenth and Fifteenth Centuries," in Promoting the Saints. Cults and Their Contexts from Late Antiquity until the Early Modern Period. Essays in Honor of Gábor Klaniczay for his 6oth Birthday, eds. Ottó Gecser, József Laszlovszky, and Balázs Nagy (Budapest, 2010), pp. 175-206, disagreed with such an opinion, being convinced instead that the common prototype spread within the Neapolitan court or in the form of a cult image brought to Hungary from the Kingdom of Sicily. The comparison with coins, indeed, is very suggestive; see especially the series of florins minted by Louis the Great in: Corpus nummorum Hungariae, ed. László Réthy, 2 vols. (Budapest, 1899-1907), II, tav. IV, nn. 62-66.

51 Kornél Szovák, "The Image of the Ideal King in Twelfth-Century Hungary (Remarks on the Legend of St Ladislas)," in Kings and Kingship in Medieval Europe, ed. Anne J. Duggan (London, 1994), pp. 241-65; László Veszprémy, "King St Ladislas, Chronicles, Legends, and Miracles," Saeculum Christianum 25 (2018), 140-63. 
Transylvania (now Hunedoara, Romania), ${ }^{52}$ constructed by John Hunyadi (1406-1456), Regent of Hungary, was certainly decorated with the portraits of Hungarian kings and captains, from the beginning up to the reign of John's son, King Matthias Corvinus (r. 1458-149o). ${ }^{53}$ We know that there were similar genealogical paintings in the castle of Zólyom (now Zvolen, Slovakia), built by Louis the Great. ${ }^{54}$

52 Szilárd Papp, "The Castle of Vajdahunyad (Hunedoara)," in The Art of Medieval Hungary, eds. Barral i Altet et al., pp. 427-30, figs. 233-34.

53 Auguste Gérando, La Transylvanie et ses habitants, seconde édition revue et augmentée (Paris, 1850), p. 378, speaks about the painting in his description of the castle: "Au-dessous des ogives, et tout autour de la salle, étaient peints les portraits des rois de Hongrie depuis Almos jusqu’à Mathias. On a dernièrement essayé de les reproduire." It is unclear whether Gérando saw fragments of it. Flóris Rómer, "Vajda-hunyadi falfestmények [Murals of Vajdahunyad]," Archaeologiai Értesíto" [Bulletin of Archeology] 5 (1871), 21-22, also discusses the paintings in the castle, commenting on an article published in the Pest Napló [Pest's Diary], which lamented the fact that the architect Imre Steindl, responsible for the castle's restoration (1870-1874) following the death of Ferenc Schulcz, wanted to destroy the paintings, even knocking down the wall on which they had been painted. Rómer wrote that he did not know of Steindl's intentions personally and doubted that things went as described in Pest Napló. The paintings, with their inscriptions, had already been described by: Lajos Arányi, Vajda-Hunyad vára. 1452. 1681. 1866. szóban és képben [Vayda-Hunyad Castle in Words and Pictures] (Poszony, 1867). He dedicated an important monograph to the castle. The fact that Arányi's excerpt, cited by Rómer, includes the names of the seven captains leads me to think that the painted genealogy also included non-royal figures, just like the Chronicon pictum: "Hatodik hunyadi kirándálásom alkalmával a nálamnál jobb szemmel biró Olilberg és Lukács urak szives segedelmével következő elvásott aláirásokat birtam az említett arczképek keretében kiolvasni: Petrus, Stephanus, Géza ... Rudolphus, Maximilianus etc. Ezen festmények tehát későbbiek és kevés műbecsüek, mert mint Yrs, Verbulch ..." [On the occasion of my sixth excursion to Hunyad, with the help of Mr. Olilberg and Mr. Lukács, who have better eyes than I have, I could read the following hardly visible signs in the frames of the above-mentioned portraits: Petrus, Stephanus, Geza ... Rudolphus, Maximilianus etc. Therefore, these paintings were made later and are of less value, than Yrs, Verbulch ...]. On the heraldic series painted on the wall of the castle's loggia: Radu Lupescu, "Lay and Ecclesiastic in the Heraldic Representation on the Matthias Loggia in Hunedoara Castle," Studia Universitatis Babeș-Bolyai. Historia $5^{8}$ (2013), 31-48.

54 On these paintings, we can read a page of John Paget's Hungary and Transylvania, with Remarks on Their Condition, Social, Political, and Economical 1 (London, 1839), p. 379: "We were shown some villainously whitewashed rooms; in one of which the ceiling is considered embellished by a series of terrible-looking figures, called Roman Emperors and Kings of Hungary. Our guide assured us the great Diet - meaning the celebrated assembly of Polish nobles under Louis I to establish the order of succession in the two countries, in 1382 - was held in this room; though, if I am not very wrong in my notion of the age of the castle, it was not then in existence. Below the floor, in another room, is a small secret chamber, where Bethlen Gábor is said to have concealed the sacred crown of saint Stephen. It is singular that, although twice chosen King, and in actual possession of the 
Drawing conclusions from these observations, we do not know who guided the illuminator in his iconographical choices nor whether the illuminator already had a large set of iconographies and composition skills on which to draw. However, the presence of King Louis the Great on the frontispiece, with all his weapons and regalia, leads us to surmise that the manuscript was a royal commission. Likewise, we do not have enough data to understand precisely who leafed through the codex and under what circumstances, although its small dimensions suggest private use. Among the many functions that the gallery of Hungarian kings could have had - medieval images are always multifaceted and polysemic - I suspect that this imagery corresponded to the desire of the patron or patrons to create a dynastic chain that could accommodate the Neapolitan king, who was a foreigner in Hungary, and his son, who was born in Hungary but to a foreign dynasty. And it was probably this purpose that determined the dominance of the chivalric ideal in the manuscript's visual story. Indeed, even the saint-kings appear as knights, defending the borders and sovereignty of their homeland against enemies, as they had sworn to do in their solemn coronation rites. ${ }^{55}$ The kings and knights of the two parallel galleries bear immediately recognizable social signs. They occupy a practicable space inside the initials, a space that in fact marginalizes them from the historical flow; they do not act, but merely exist. In this way, they are more idola than simulacra: with no naturalistic intent, the illuminator presents not real kings or knights but rather sort of avatars of the ideas of royalty and chivalry.

\section{Bibliography}

\section{Primary Sources}

Andreas aulae regiae capellanus/königlicher Hofkapellan, De amore libri tres/Von der Liebe drei Bücher, Text nach der Ausgabe von E. Trojel. Übersetzt und mit Anmerkungen und einem Nachwort versehen von Fritz Peter Knapp (Berlin 2006). Chronique d'Edmund Dynter 3 (Bruxelles, 1857).

crown, this champion of Protestantism never placed it on his head, though it is highly probable that it might have secured him the throne."

"Regnum sibi commissum et iura regalia non minuere nec alienare, sed potius augere et male alienata hactenus, secundum datam sibi gratiam, ad ius pristinum revocare." For a discussion of this text and its figurative projections, see: Vinni Lucherini, "Raffigurazione e legittimazione della regalità nel primo Trecento: una pittura murale con l'incoronazione di Carlo Roberto d'Angiò a Spišská Kapitula (Szepeshely)," in Medioevo: natura e figura, ed. Arturo Carlo Quintavalle (Milan, 2015), pp. 675-87. 
Jean de Jandun, "Éloge de Paris," in Paris et ses historiens aux XIV et XVe siècles.

Documents et écrits originaux, eds. Antoine Jean Victor Leroux de Lincy, and LazareMaurice Tisserand (Paris, 1867).

Rubió i Lluch, Antoni, Documents per l'història de la cultura catalana mig-eval, 2 vols (Barcelona, 1908-1921).

Scriptores rerum Hungaricarum, ed. Joannes Georg Schwandtner (Tyrnaviae, 1765).

Simon de Kéza, Gesta Hungarorum, eds. László Veszprémy, and Frank Schaer, with a study by Jenő Szücs (Budapest, 1999).

Simon of Kéza, The Deeds of the Hungarians, ed. László Veszprémy, and Frank Schaer, with a Study of Jenö Szücs (Budapest, 1999).

Soldevila, Ferran, Les quatre grans cròniques, ed. Josep Massot i Muntaner (revisió filològica de Jordi Brugera, revisió històrica de Maria Teresa Ferrer i Mallol): 1. Llibre dels feits del re en Jaume (Barcelona, 2007), 2. Crònica de Bernat Desclot (Barcelona, 2008), 3. Crònica de Ramon Muntaner (Barcelona, 2011), 4. Crònica de Pere III el Cerimoniòs (Barcelona, 2014), 5. Apèndix i index (Barcelona 2016), with an essay by Maria Teresa Ferrer i Mallol, "Les quatre grans Cròniques: una visió de conjunt," $13-73$.

\section{Secondary Sources}

Arányi, Lajos, Vajda-Hunyad vára. 1452. 1681. 1866. szóban és képben [Vayda-Hunyad Castle in Words and Pictures] (Poszony, 1867).

Aurell, Jaume, Authoring the Past. History, Autobiography and Politics in Medieval Catalonia (Chicago, 2012).

Barral i Altet, Xavier, "Forme di narrazione medievale, con o senza 'storie,' al servizio del potere," Hortus artium medievalium 21 (2015), 6-20.

Bautier, Robert-Henri, "Échanges d'influences dans les chancelleries souveraines du Moyen Âge, d'après les types de sceaux de majesté," in Académie des inscriptions et belles-lettres, Comptes-rendus des séances de l'année 1968 (Paris, 1968), 192-200.

Bedos-Rezak, Brigitte M., "Medieval Identity: A Sign and a Concept," in Medieval Coins and Seals: Constructing Identity, Signifying Power, ed. Susan Solway (Turnhout, 2015), pp. 23-63.

Bennert, Uwe, "Art et propagande politique sous Philippe IV le Bel: le cycle des rois de France dans la Grand'salle du palais de la Cité," Revue de l'art 97 (1992), 46-59.

Bozóky, Edina, Attila et les Huns. Vérités et legendes (Paris, 2012).

Brown, Elizabeth A. R., "Philip the Fair and His Family: His Sons, Their Marriages, and Their Wives," Medieval Prosopography 32 (2017), 125-85.

Carqué, Bernd, "Non erat homo, nec bestia, sed imago. Vollplastische Bildwerke am Hof Philipps IV. von Frankreich und die Medialität der Gattung," in Bilder der Macht in Mittelalter und Neuzeit. Byzanz, Okzident, Russland, eds. Otto Gerhard Oexle, and Michail A. Bojcov (Göttingen, 2007), pp. 187-242. 
Caucheteux-Chavannes, Marjolaine, Les sceaux des rois de France d'Hugues Capet à François I ${ }^{\text {er }}$ (987-1547) (Paris, 1962).

Cawsey, Suzanne F., Kingship and Propaganda. Royal Eloquence and the Crown of Aragon c. 1200-1450 (Oxford, 2002).

Cingolani, Stefano Maria, Historiografia, propaganda i comunicació al segle XIII: Bernat Desclot i les dues redaccions de la seva Crònica (Barcelona, 2006).

Coldstream, Nicola, review of Dorothy Gilllerman, Enguerran de Marigny and the Church of Notre-Dame at Ecouis. Art and Patronage in the Reign of Philip the Fair (University Park, 1994), in Speculum 71/4 (1996), 949-51.

Corpus nummorum Hungariae, ed. László Réthy, 2 vols. (Budapest, 1899-1907).

Dalas-Garrigues, Martine, "Le premier sceau de substitution de Charles V," Bibliothèque de l'École des chartes 144/2 (1986), 355-59.

Dalas-Garrigues, Martine, Corpus des sceaux français du Moyen Âge 2. Les sceaux des rois et de régence (Paris, 1991).

Das Porträt vor der Erfindung des Porträts, eds. Martin Büchsel, and Peter Schmidt (Mainz, 2003).

Davis, Michael, "Désespoir, Espérance, and Douce France: The New Palace, Paris, and the Royal State," in Fauvel Studies. Allegory, Chronicle, Music and Image in Paris, Bibliothèque Nationale de France, MS français 146, eds. Margaret Bent, and Andrew Wathey (Oxford, 1998), pp. 187-213.

Davis, Michael T., "The Architecture of the Collège of Navarre in Paris," in Medieval Women and Their Objects, eds. Jenny Adams, and Nancy Mason Bradbury (Ann Arbor, 2017), pp. 71-96.

de Cevins, Marie-Madeleine, Saint Étienne de Hongrie (Paris, 2004).

de Laborderie, Olivier, "La mémoire des origines Normandes des rois d'Angleterre dans les généalogies en rouleau des XIII e et XIV ${ }^{\mathrm{e}}$ siècles," in La Normandie et l'Angleterre au Moyen Âge, Colloque de Crécy-la-Salle (4-7 octobre 20o1), eds. Pierre Bouzet, and Véronique Gazeau (Caen, 2003), pp. 211-36.

de Laborderie, Olivier, Histoire, mémoire et pouvoir. Les généalogies en rouleau des rois d'Angleterre, 1250-1422 (Paris, 2013).

Delisle, Léopold, "Notice sur les manuscrits de Bernard Gui," Notices et extraits des manuscrits de la Bibliothèque nationale et autres bibliothèques 27/2 (1879), 245-52.

de Mérindol, Christian, "Portrait et généalogie: la genèse du portrait réaliste et individualisé," in Population et demographie au Moyen Âge, ed. Oliver Guyotjeannin (Paris, 1995), pp. 219-48.

de Mérindol, Christian, "L'héraldique des princes angevins," in Les princes angevins $d u$ $X I I I^{e}$ au $X V^{e}$ siècle: un destin européen, eds. Noël-Yves Tonnerre, and Élisabeth Verry (Rennes, 2004), pp. 277-307.

de Vajay, Szabolcs, "L'héraldique image de la psychologie sociale," Atti dell'Accademia Pontaniana 16 (1967), 5-19. 
Diez, Friedrich, Beiträge zur Kenntniss der romantischen Poesie. Erstes Heft (Berlin, 1825).

Diez, Friedrich, "Essais sur les Cours d'amour, traduit de l'allemand et annoté par M. le baron C. de Roisin," Mémoires de la Société royale des sciences, de l'agriculture et des arts de Lille (1841), 147-272.

Eastern Europe in the Middle Ages (500-1300), ed. Florin Curta (Leiden, 2019).

Engel, Pál, The Realm of St Stephen. A History of Medieval Hungary 895-1526 (New York, 2001).

Engel, Pál, Kristó, Gyula, and Kubinyi, András, Histoire de la Hongrie médiévale 2. Des Angevins aux Habsbourg (Rennes, 2008).

Erlande-Brandenburg, Alain, "La priorale Saint-Louis de Poissy," Bulletin Monumental 129/2 (1971), 85-112.

Fügedi, Erik, "The Aristocracy in Medieval Hungary," in Kings, Bishops, Nobles and Burghers in Medieval Hungary, ed. János M. Bak (London, 1986), pp. 1-14.

Georg, Johann, Prinz von Hohenzollern, Die Königsgalerie der französischen Kathedrale. Herkunft, Bedeutung, Nachfolge (Munich, 1965).

Gérando, Auguste, La Transylvanie et ses habitants, seconde édition revue et augmentée (Paris, 1850).

Gerlitz, Iris, “'The King is Dead, Long Live the King': Representing Transfer of Power in the Crusader Estoire de Eracles," in Between Jerusalem and Europe. Essays in Honour of Bianca Kühnel, eds. Renana Bartal, and Hanna Vorholt (Leiden, 2015), pp. 34-54.

Gilllerman, Dorothy, Enguerran de Marigny and the Church of Notre-Dame at Ecouis. Art and Patronage in the Reign of Philip the Fair (University Park, 1994).

Guenée, Bernard, "Les généalogies entre l'histoire et la politique: la fierté d'être Capétien, en France, au Moyen Âge," Annales. Histoire, Sciences Sociales 33/3 (1978), $450-77$.

Guenée, Bernard, “Les Grandes Chroniques de France, le roman aux roys (1274-1518)," in Les Lieux de mémoire 2. La Nation, ed. Pierre Nora (Paris, 1986), pp. 189-214.

Guérout, Jean, "Le Palais de la Cité à Paris des origines à 1417. Essai topographique et archéologique," Mémoires de la Féderation des Sociétés historiques et archéologiques de Paris et de l'Île-de-France 1 (1949), 57-212; 2 (1950), 21-204; 3 (1951), 7-101.

Guyot-Bachy, Isabelle, and Moeglin, Jean-Marie, "Comment ont été continuées les Grandes Chroniques de France dans la première moitié du XIV e siècle," Bibliothèque de l'École des chartes 163/2 (2005), 385-433.

Hedeman, Anne D., The Royal Image. Illustrations of the Grandes Chroniques de France 1274-1422 (Berkeley, 1991).

Hedeman, Anne D., "Presenting the Past: Visual Translation in Thirteenth- to FifteenthCentury France," in Imagining the Past in France. History in Manuscript Painting 1250-1500, eds. Elizabet Morrison, and Anne D. Hedeman (Los Angeles, 2010), pp. $69-88$. 
Hedeman, Anne D., “Constructing Saint Louis in John the Good's Grandes Chroniques de France (Royal MS 16 G. VI)," Electronic British Library Journal 19 (2014), http:// www.bl.uk/eblj/2014articles/article1o.html. Accessed 2020 April 15.

Holladay, Joan A., "Kings, Notaries, and Merchants. Audience and Image in the Grand'salle of the Palace at Paris," in Ritual, Images, and Daily Life. The Medieval Perspective, ed. Gerhard Jaritz (Münster, 2012) pp. 75-94.

Holladay, Joan A., Genealogy and the Politics of Representation in the High and Late Middle Ages (Cambridge, 2019).

Idoneität - Genealogie - Legitimation. Begründung und Akzeptanz von dynastischer Herrschaft im Mittelalter, eds. Cristina Andenna, and Gert Melville (Cologne, 2015).

Jékely, Zsombor, “A magyar királyok genealógiai ciklusa a leleszi premontrei kolostorkápolna középkori falképein [Genealogical Cycle of Hungarian Kings on the Medieval Frescoes at the Premonstratensian Abbey of Lelesz (Leles, Slovakia)]," Mưvészettörténeti Értesítő [Bulletin of Art History] 61 (2012), 175-86.

Jékely, Zsombor, "Narrative Structure of the Painted Cycle of a Hungarian Holy Ruler: The Legend of Saint Ladislas," Hortus artium medievalium 21 (2015), 62-74.

Joy, Diane, "Un manifeste politique des Valois: le programme statuaire du palais de Poitiers sous Jean de Berry," in Regards croisés sur le monument medieval. Mélanges offerts à Claude Andrault-Schmitt, ed. Marcello Angheben (Turnhout, 2018), pp. 431-44.

Karl IV. Kaiser von Gottes Gnaden. Kunst und Repräsentation des Hauses Luxemburg 1310-1437, ed. Jiří Fajt (Prague, 2006).

Karnein, Alfred, De amore in volksprachlicher Literatur. Untersuchungen zur Andreas Capellanus-Rezeption in Mittelalter und Renaissance (Heidelberg, 1985).

Klaniczay, Gábor, “Rois saints et les Anjou de Hongrie," Alba Regia 12 (1985), 57-66.

Klaniczay, Gábor, "Le culte des saints dynastiques en Europe centrale (Angevins et Luxembourg au XIV e siècle)," in L'Église et le peuple chrétien dans les pays de l'Europe du centre-est et du nord, XIV e-XVe siècles (Rome, 1990), pp. 221-47.

Klaniczay, Gábor, "L'image chevaleresque du saint roi au XII siècle," in La royauté sacrée dans le monde chrétien, Actes du colloque (Royaumont, mars 1989), eds. Alain Boureau, and Claudio-Sergio Ingerflom (Paris, 1992), pp. 53-61.

Klaniczay, Gábor, "La noblesse et le culte des saints dynastiques sous les rois angevins," in La noblesse dans les territoires angevins à la fin du Moyen Âge, eds. Noël Coulet, and Jean-Marie Matz (Rome, 200o), pp. 511-26.

Klaniczay, Gábor, Holy Rulers and Blessed Princesses. Dynastic Cults in Medieval Central Europe (Cambridge, 2002).

Klaniczay, Gábor, "San Ladislao d'Ungheria athleta patriae," in La lettera e lo spirito. Studi di cultura e vita religiosa (secc. XII-XV) per Edith Pásztor, eds. Marco Bartoli, Letizia Pellegrini, and Daniele Solvi (Milan, 2016), pp. 157-78. 
Klapisch-Zuber, Christiane, L'ombre des ancêtres. Essai sur l'imaginaire médiéval de la parenté (Paris, 2000).

Klein, Bruno, "Comment parler des arts au XIVe siècle? La genèse du panthéon aragonais-catalan à Pöblet à l'époque du roi Pierre le Cérémonieux," in Visualisierung und kultureller Transfer, eds. Kirstin Kramer, and Jens Baumgarten (Würzburg, 2009), pp. 83-10o.

Kozlowsli, Sarah K., "Panel Painting Between the Courts of Naples and Hungary. A Hypothesis for Simone Martini's Saint Ladislaus and a Painting of Christ on the Cross," Convivium 6 (2O20), 79-97.

Kristó, Gyula, Histoire de la Hongrie médiévale. I. Le temps des Arpad (Rennes, 2000).

Kunst als Herrschaftsinstrument. Böhmen und das Heilige Römische Reich unter den Luxemburgern im europäischen Kontext, eds. Jiří Fajt, and Andrea Langer (Berlin, 2009).

La fantasia e la storia. Studi di Storia dell'arte sul ritratto dal Medioevo al Contemporaneo, ed. Giulio Brevetti (Palermo, 2019).

Lamarrigue, Anne-Marie, "La rédaction d'un catalogue des rois de France. Guillaume de Nangis et Bernard Gui," in Saint-Denis et la Royauté, eds. Françoise Autrand, Claude Gauvard, and Jean-Marie Moeglin (Paris, 1999), pp. 481-92.

Lautier, Claudine, "Les deux galeries des rois de la cathédrale de Chartres," Bulletin monumental 169 (2011), 41-64.

Léglu, Catherine, "A Genealogy of the Kings of England in Papal Avignon: British Library, Egerton MS 1500," Electronic British Library Journal 18 (2013), http://www .bl.uk/eblj/2013articles/article18.html. Accessed 2020 April 15.

Liaño Martínez, Emma, "Aloy de Montbray imaginator. Del Reino de Francia a la Corona d'Aragón en le siglo XIV," Locus Amœenus 12 (2013-14), 29-53.

L'individu au Moyen Âge. Individuation et individualisation avant la modernité, eds. Brigitte M. Bedos-Rezak, and Dominique Iogna-Prat (Paris, 2005).

Lombard-Jourdan, Anne, “Montjoies and Montjoie dans la plaine Saint-Denis," Mémoires de la Fédération des sociétés historiques et archéologiques de Paris et de l'Ile-de-France 25 (1974), 141-81.

Lucherini, Vinni, "The Journey of Charles I, King of Hungary, from Visegrád to Naples (1333): Its Political Implications and Artistic Consequences," The Hungarian Historical Review. New Series of Acta Historica Academiae Scientiarum Hungariae 2 (2013), 341-62.

Lucherini, Vinni, "Il Chronicon pictum ungherese (1358): racconto e immagini al servizio della costruzione dell'identità nazionale," Rivista di Storia della Miniatura 19 (2015), 58-72.

Lucherini, Vinni, "Raffigurazione e legittimazione della regalità nel primo Trecento: una pittura murale con l'incoronazione di Carlo Roberto d'Angiò a Spišská Kapitula 
(Szepeshely)," in Medioevo: natura e figura, ed. Arturo Carlo Quintavalle (Milan, 2015), pp. 675-87.

Lucherini, Vinni, "Le fonti antiche del Chronicon pictum ungherese (1358): narrare le origini della nazione e trasporle in immagini," Incidenza dell'antico 14/1 (2016), 61-88.

Lucherini, Vinni, “La rinuncia di Ludovico d'Angiò al trono e il problema della successione nei regni di Napoli e d'Ungheria: sfide giuridiche e artistiche," in Da Ludovico d'Angiò a san Ludovico di Tolosa. I testi e le immagini, eds. Teresa D'Urso, Alessandra Perriccioli, and Daniele Solvi (Spoleto, 2017), pp. 137-52.

Lucherini, Vinni, "The Artistic Visualization of the Concept of Kingship in Angevin Hungary," in The Art of Medieval Hungary, eds. Xavier Barral i Altet, Pál Lővei, Vinni Lucherini, and Imre Takács (Rome, 2018), pp. 235-51.

Lucherini, Vinni, "The Hungarian Illuminated Chronicle (Pls. 44-47)," in The Art of Medieval Hungary, eds. Xavier Barral i Altet, Pál Lővei, Vinni Lucherini, and Imre Takács (Rome, 2018), pp. 409-12.

Lucherini, Vinni, La Cronaca angioina dei re d'Ungheria. Uno specchio eroico e fiabesco della sovranità (Paris, 2021).

Luchitskaya, Svetlana I., “Ad succurrendum. Wie starben die Könige von Jerusalem?” Mediaevistik 22 (2009), 49-82.

Luchitskaya, Svetlana I., "Pictorial Sources, Coronation Ritual, and Daily Life in the Kingdom of Jerusalem," in Ritual, Images, and Daily Life. The Medieval Perspective, ed. Gerhard Jaritz (Münster, 2012), pp. 49-74.

Lupescu, Radu, "Lay and Ecclesiastic in the Heraldic Representation on the Matthias Loggia in Hunedoara Castle," Studia Universitatis Babeș-Bolyai. Historia 58 (2013), 31-48.

Marosi, Ernö, "Die drei Majestätssiegel König Karl Roberts von Ungarn," in Akten des XXV. Internationalen Kongresses für Kunstgeschichte (Wien, 4.-10. September 1983), eds. Hermann Fillitz, and Martina Pippal, 9 vols. (Wien, 1984-1986), 6 Europäische Kunst um 1300 (Wien, 1986), pp. 249-56.

Marosi, Ernö, "Der heilige Ladislaus als ungarischer Nationalheiliger. Bemerkungen zu seiner Ikonographie im 14.-15. Jh., Acta historiae artium Hungariae 33 (1987), 232-34.

Marosi, Ernö, Kép és hasonmás. Müvészet és valóság a 14.-15. századi Magyarországon [Image and Likeness: Art and Reality in the 14th and 15th Centuries in Hungary] (Budapest, 1995).

Marosi, Ernö, "Saints at Home and Abroad. Some Observations on the Creation of Iconographic Types in Hungary in the Fourteenth and Fifteenth Centuries," in Promoting the Saints. Cults and Their Contexts from Late Antiquity until the Early Modern Period. Essays in Honor of Gábor Klaniczay for his 6oth Birthday, eds. Ottó Gecser, József Laszlovszky, and Balázs Nagy (Budapest, 2010), pp. 175-206. 
Marosi, Ernö, “The Illuminations of the Chronicle," in Studies on the Illuminated Chronicle, eds. János M. Bak, and László Veszprémy (Budapest, 2018), pp. 25-110.

Martindale, Andrew, Heroes, Ancestors, Relatives and the Birth of the Portrait. The Fourth Gerson Lecture, held in memory of Horst Gerson (1907-1978) in the aula of the University of Groningen on May 26, 1988 (Maarsen, 1988).

Melville, Gert, "Spätmittelalterliche Genealogien als dynastische Legitimation zur Herrschaft," in Die Familie als historischer und sozialer Verband. Untersuchungen zum Spätmittelalter und zur frühen Neuzeit, ed. Peter-Johannes Schuler (Sigmaringen, 1987), pp. 204-309.

Musson, Anthony, "The Power of Images: Allusion and Intertextuality in Illuminated English Law Books," in Citation, Intertextuality and Memory in the Middle Ages and Renaissance. 1. Text, Music and Image from Machaut to Ariosto, eds. Yolanda Plumley, Stefano Jossa, and Giuliano Di Bacco (Exeter, 2011), pp. 113-26.

Năstăsoiu, Dragoș-Gheorghe, Between Personal Devotion and Political Propaganda: Iconographic Aspects in the Representation of the sancti reges Hungariae in Church Mural Painting (14th Century - Early 6 th Century), PhD, Central European University of Budapest (Budapest, 2018).

Newton, Stella M., "Tomaso da Modena, Simone Martini, Hungarians and St. Martin in Fourteenth Century Italy," Journal of Warburg and Courtauld Institutes 63 (1980), 234-38.

Paget, John, Hungary and Transylvania, with Remarks on Their Condition, Social, Political, and Economical 1 (London, 1839).

Papp, Szilárd, "The Castle of Vajdahunyad (Hunedoara)," in The Art of Medieval Hungary, eds. Xavier Barral i Altet, Pál Lővei, Vinni Lucherini, and Imre Takács (Rome, 2018), pp. 427-30.

Perkinson, Stephen, "Portraits and Counterfeits: Villard de Honnecourt and Thirteenth-Century Theories of Representation," in Excavating the Medieval Image. Manuscripts, Artists, Audiences. Essays in Honor of Sandra Hindman, eds. David S. Areford, and Nina Rowe (Aldershot, 2004), pp. 13-28.

Perkinson, Stephen, "Rethinking the origins of portraiture," Gesta 46/2 (2007), 135-157.

Perkinson, Stephen, The Likeness of the King. A Prehistory of Portraiture in Late Medieval France (Chicago, 2009).

Perkinson, Stephen, “Likeness," Studies in Iconography 33 (2012), Special Issue Medieval Art History Today - Critical Terms, 15-28.

Polzer, Joseph, "L'ultimo dipinto di Simone Martini," Antichità viva 19/6 (1980), 7-16.

Prague. The Crown of Bohemia 1347-1437, eds. Barbara Drake Boehm, and Jiří Fajt (New York, 2005).

Rácz, György, “L'araldica dell'età angioina," in L'Ungheria angioina, ed. Enikő Csukovits (Rome, 2013), pp. 283-318. 
Radaelli, Anna, “Tra finzione e realtà: la conplancha per Roberto d'Angiò, una voce per un re immaginato," Lecturae tropatorum 11 (2018), 1-69.

Rady, Martyn C., Nobility, Land and Service in Medieval Hungary (London, 200o).

Rathmann-Lutz, Anja, Images Ludwigs des Heiligen im Kontext dynastischer Konflikte des 14. und 15. Jahrhunderts (Berlin, 2010).

Recht, Roland, "Le portrait et le principe de réalité dans la sculpture: Philippe le Bel et l'image royale," in Akten des XXV. Internationalen Kongresses für Kunstgeschichte 6 , ed. Elisabeth Liskar (Vienna, 1986), pp. 189-201.

Rómer, Flóris, "Vajda-hunyadi falfestmények [Murals of Vajdahunyad]," Archaeologiai Értesíto" [Bulletin of Archeology] 5 (1871), 21-22.

Rosario, Iva, Art and Propaganda. Charles IV of Bohemia, 1346-1378 (Woodbridge, 2000).

Rosen, Klaus, Attila. Der Schrecken der Welt (München, 2016).

Sandron, Dany, review of, Dorothy Gilllerman, Enguerran de Marigny and the Church of Notre-Dame at Ecouis. Art and Patronage in the Reign of Philip the Fair (University Park, 1994), in Bulletin monumental 154/2 (1996), 184-87.

Schmidt, Gerhard, "Bemerkungen zur Königsgalerie der Kathedrale von Reims," Wiener Jahrbuch für Kunstgeschichte 25 (1972), 96-106.

Schmidt, Gerhard, "Porträt oder Typus: zur Frage der Ähnlichkeit in den Darstellungen Kaiser Friedrichs III," Jahrbuch des Kunsthistorischen Museums Wien 8/9 (2006), 10-59.

Schramm, Percy Ernst, Sphaira, Globus, Reichsapfel. Wanderung und Wandlung eines Herrschaftszeichens von Cäsar bis zu Elisabeth II. Ein Beitrag zum Nachleben der Antike (Stuttgart, 1958).

Serra Desfilis, Amadeo, "La historia de la dinastía en imágenes: Martín el Humano y el rollo genealógico de la Corona de Aragón," Locus Amonus 6 (2002-03), 58-74.

Set in Stone. The Face in Medieval Sculpture, exhibition catalogue, ed. Charles T. Little (New Haven, 2006).

Sherman, Claire Richter, The Portraits of Charles Vof France (New York, 1969).

Šmahel, František, The Parisian Summit, 1377-78. Emperor Charles IV and King Charles Vof France (Prague, 2014).

Spence,John, Reimagining HistoryinAnglo-NormanProse Chronicles(Woodbridge, 2013). Spiegel, Gabrielle M., "The Reditus Regni ad Stirpem Karoli Magni: A New Look," French Historical Studies 7 (1971), 145-74.

Spiegel, Gabrielle, "Genealogy. Form and Function in Medieval Historical Narrative," History and Theory 22/1 (1983), 43-53.

Spiegel, Gabrielle, "Structures of Time in Medieval Historiography," The Medieval History Journal 19/1 (2016), 21-33.

Stejskal, Karel, "Die Rekonstruktion des Luxemburger Stammbaums auf Karlstein," Umëni 26 (1978), 535-63.

Stejskal, Karel, L'Empereur Charles IV: l'art en Europe au XIVe siècle (Paris, 1980). 
Strongman, Sheila, "John Parker's Manuscripts: an Edition of the Lists in Lambeth Palace MS 737," Transactions of the Cambridge Bibliographical Society 7 (1977-80), 1-27.

Studies on the Illuminated Chronicle, eds. János M. Bak, and László Veszprémy (Budapest, 2018).

Suckale, Robert, "Zur Ikonografie der deutschen Herrscher des 14. Jahrhunderts. Rudolf I. - Ludwig IV. - Karl IV.," in Die Goldene Bulle. Politik, Wahrnehmung, Rezeption, eds. Ulrike Hohensee, Mathias Lawo, Olaf B. Rader, and Michael Lindner (Berlin, 20o9), pp. 327-48.

Szovák, Kornél, "The Image of the Ideal King in Twelfth-Century Hungary (Remarks on the Legend of St Ladislas)," in Kings and Kingship in Medieval Europe, ed. Anne J. Duggan (London, 1994), pp. 241-65.

Takács, Imre, "Deux joyaux armoriés," in Sigismund rex et imperator. Art et culture à l'époque de Sigismond de Luxembourg 1387-1437, exhibition catalogue, ed. Imre Takács (Budapest, 2006), pp. 101-02.

Takács, Imre, "L'art de la cour royale à la fin de l'époque angevine," in Sigismund rex et imperator. Art et culture à l'époque de Sigismond de Luxembourg 1387-1437, exhibition catalogue, ed. Imre Takács (Budapest, 2006), pp. 68-86.

Takács, Imre, Az Árpád-házi királyok pecsétjei [Royal Seals of the Arpad Dynasty] (Budapest, 2012).

The Capetian Century 1214 to 1314, eds. William Chester Jordan, and Jenna Rebecca Philipps (Turnhout, 2017).

The Hungarian Illuminated Chronicle, ed. Dezső Dercsényi (Budapest, 1969).

Turel, Noa, "Living Pictures: Rereading 'Au Vif,' 1350-1550," Gesta 5o/2 (2011), 163-82.

Valois, Noël, "Les statues de la grande salle du Palais," Bulletin de la Société de l'histoire de Paris et de l'île de France 30/1 (1903), 87-90.

Veszprémi, László, Wehli, Tünde, and Hapák, József, The Book of the Illuminated Chronicle (Budapest, 2009).

Veszprémy, László, "King St Ladislas, Chronicles, Legends, and Miracles," Saeculum Christianum 25 (2018), 140-63.

Veszprémy, László, "The Knightly Culture of the Hungarian Barons of the Angevin Period: Ideals and Practice," in Formations et cultures des officiers et de l'entourage des princes dans les territoires angevins (milieu XIII ${ }^{e}$ - fin XVe siècle), eds. Isabelle Mathieu, and Jean-Michel Matz (Rome, 2019), pp. 297-314.

Villette, Jean, "Les galeries des rois aux façades des cathédrales. Rois de France ou rois de Juda?," Mémoires de la Société Archéologique d'Eure-et-Loir 31/4 (1991), 143-68.

Zichy, Graf Istvan, "Die Miniaturen der Ungarischen Bilderchronik und die Kostümkunde," in Petrovics Elekemlékkönyv-Hommage à Alexis Petrovics (Budapest, 1934), pp. 59-70, 191-97.

Zupka, Dušan, Ritual and Symbolic Communication in Medieval Hungary Under the Árpád Dynasty, 1000-1301 (Leiden, 2016). 


\section{Illustrations}

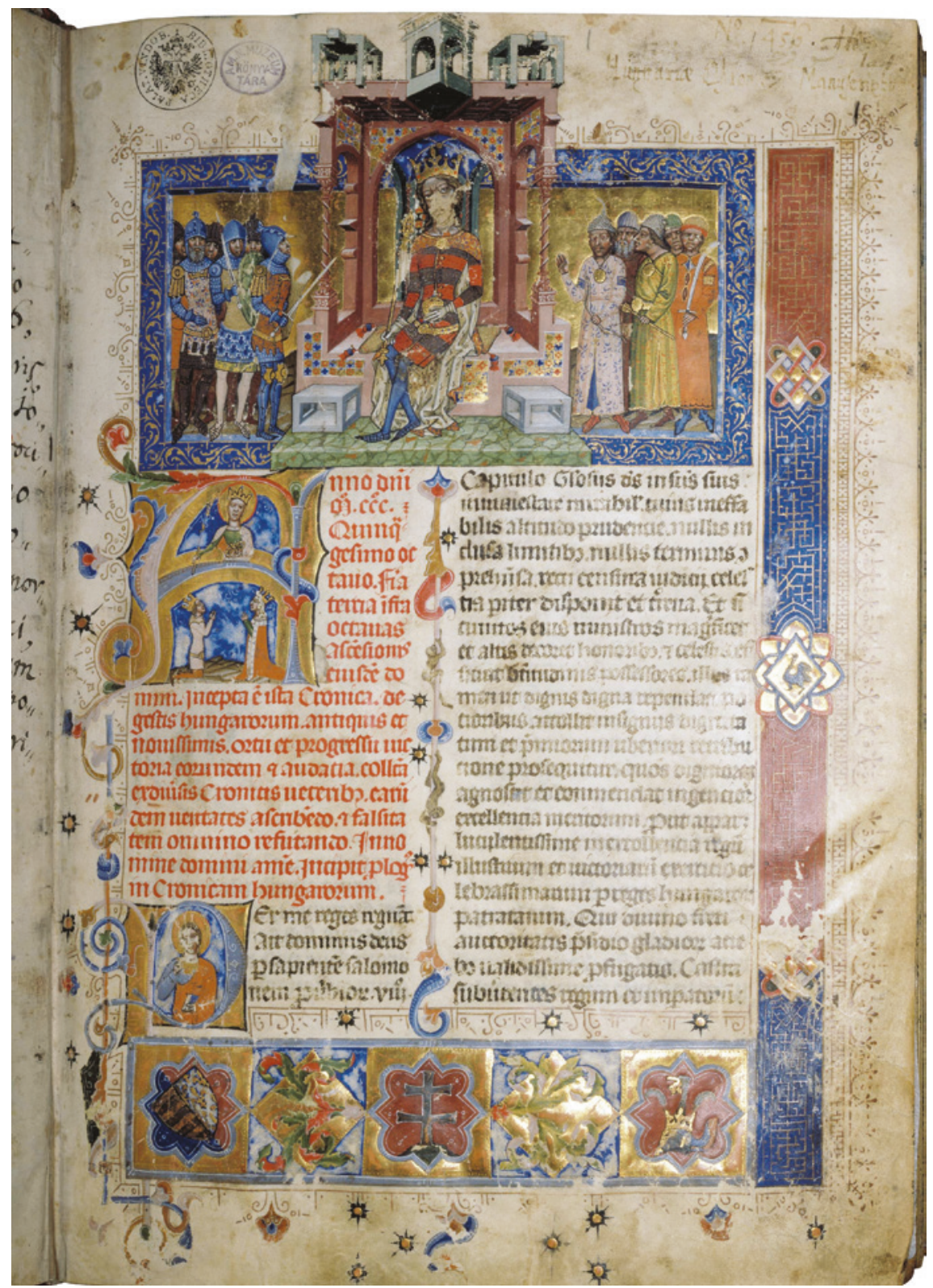

FIGURE 8.1 Budapest, Országos Széchényi Könyvtár, Cod. Lat. 404, fol. ir (C) BUDAPEST, ORSZÁGOS SZÉCHÉNYI KÖNYVTÁR 


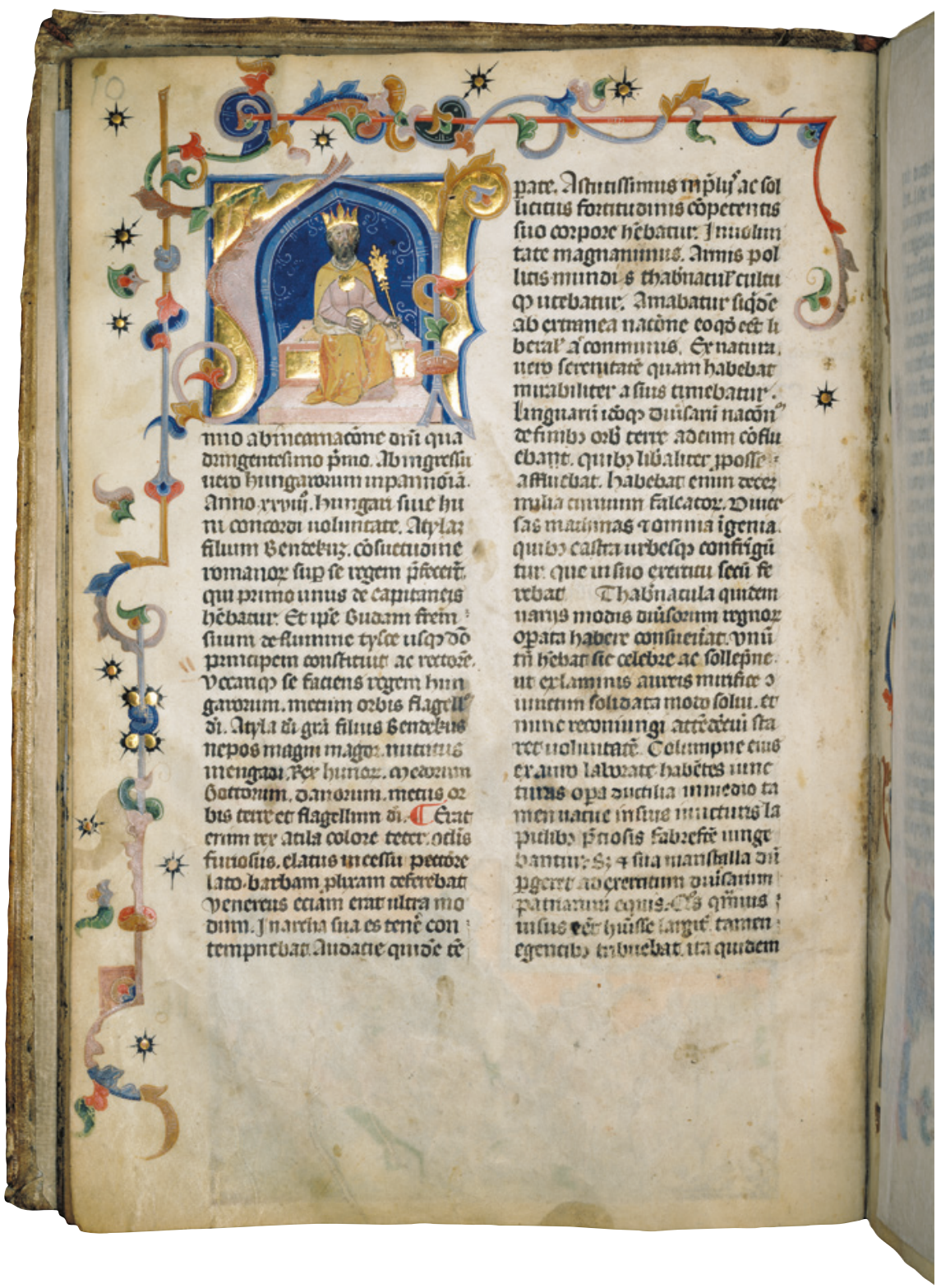

FIGURE 8.2 Budapest, Országos Széchényi Könyvtár, Cod. Lat. 404, fol. $5 \mathrm{~V}$

(C) BUDAPEST, ORSZÁGOS SZÉCHÉNYI KÖNYVTÁR 


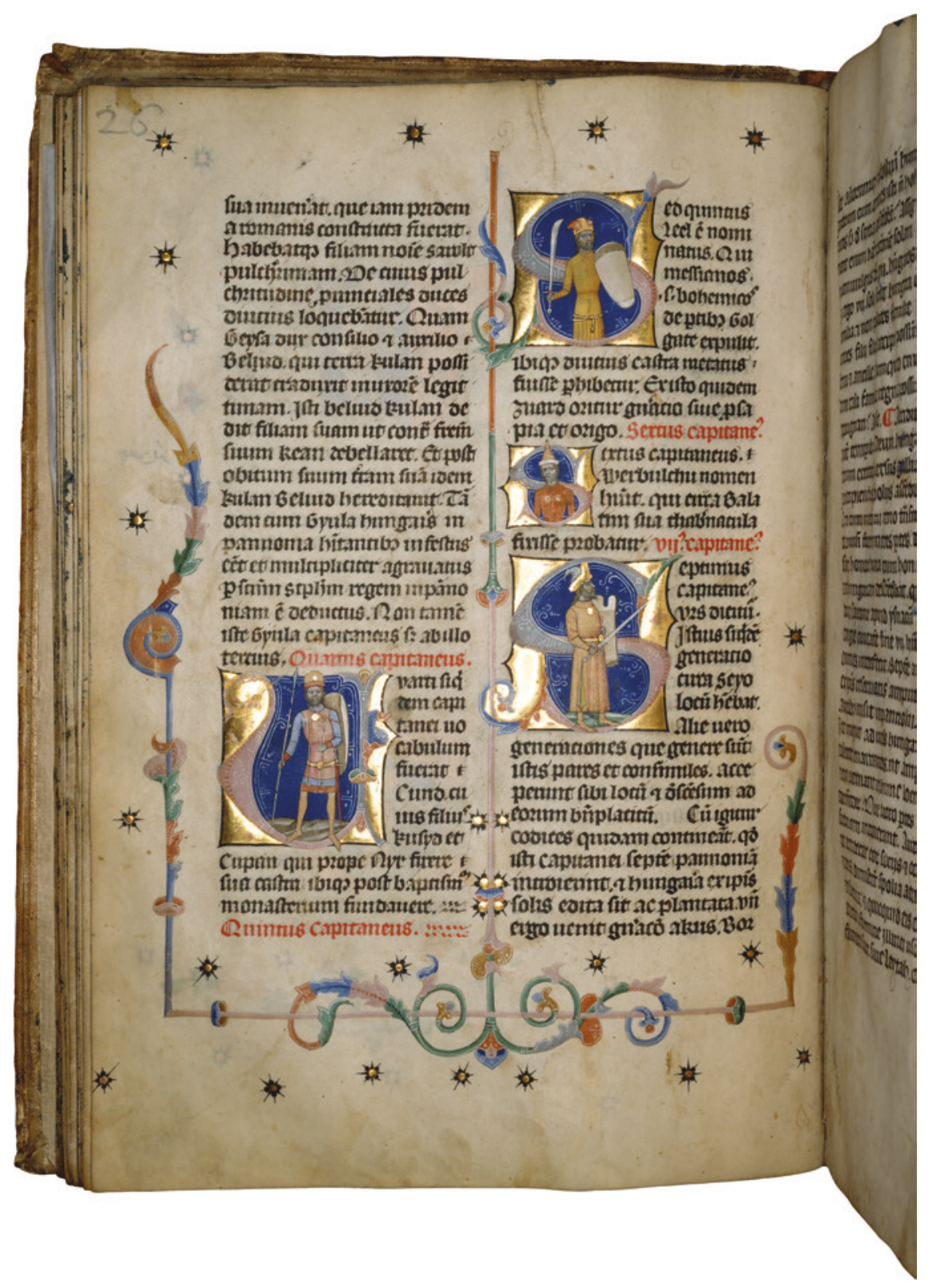

FIGURE 8.3 Budapest, Országos Széchényi Könyvtár, Cod. Lat. 404, fol. 13V

(C) BUDAPEST, ORSZÁGOS SZÉCHÉNYI KÖNYVTÁR 


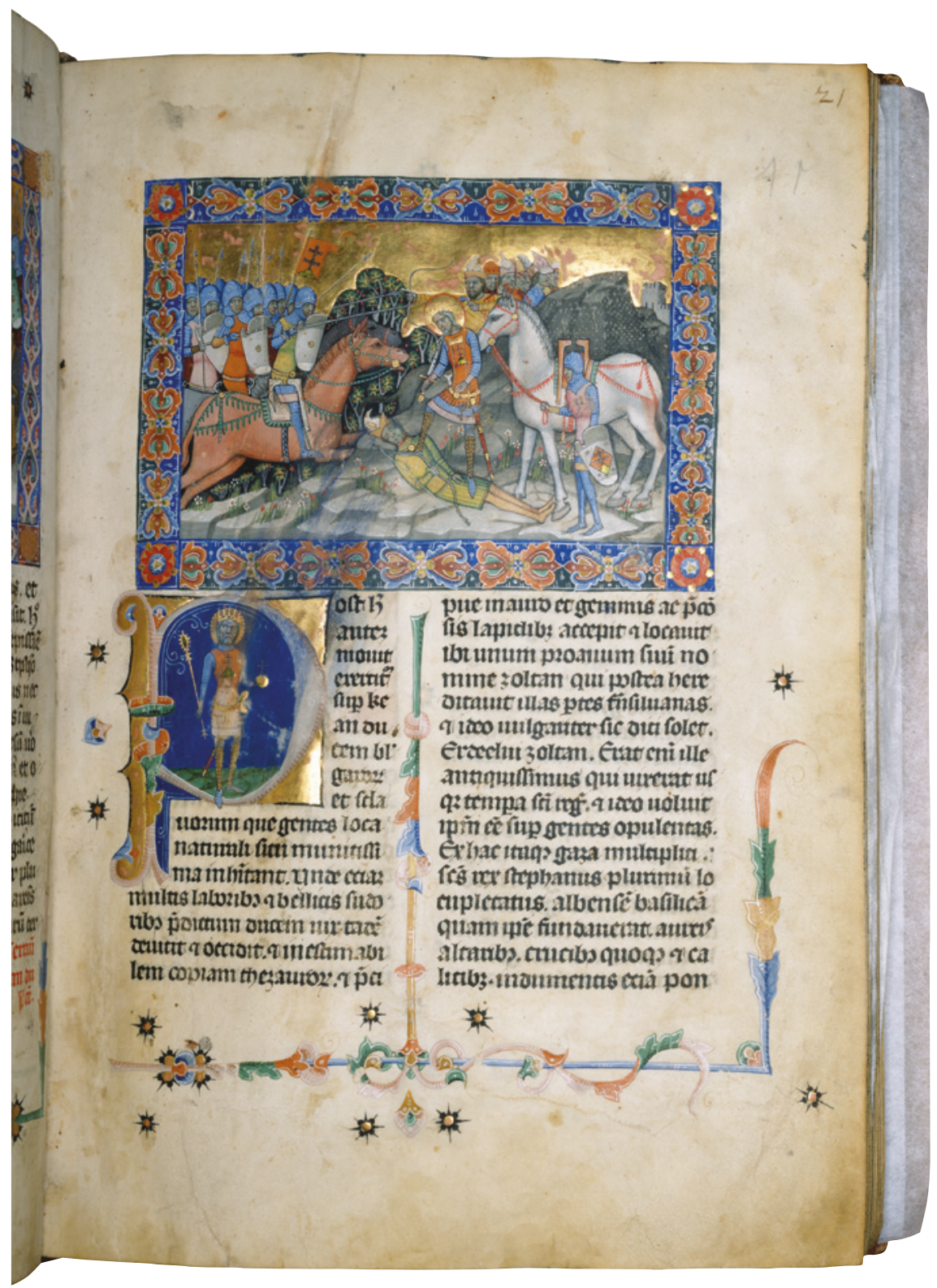

FIGURE 8.4 Budapest, Országos Széchényi Könyvtár, Cod. Lat. 404, fol. $21 r$

(C) BUDAPEST, ORSZÁGOS SZÉCHÉNYI KÖNYVTÁR 


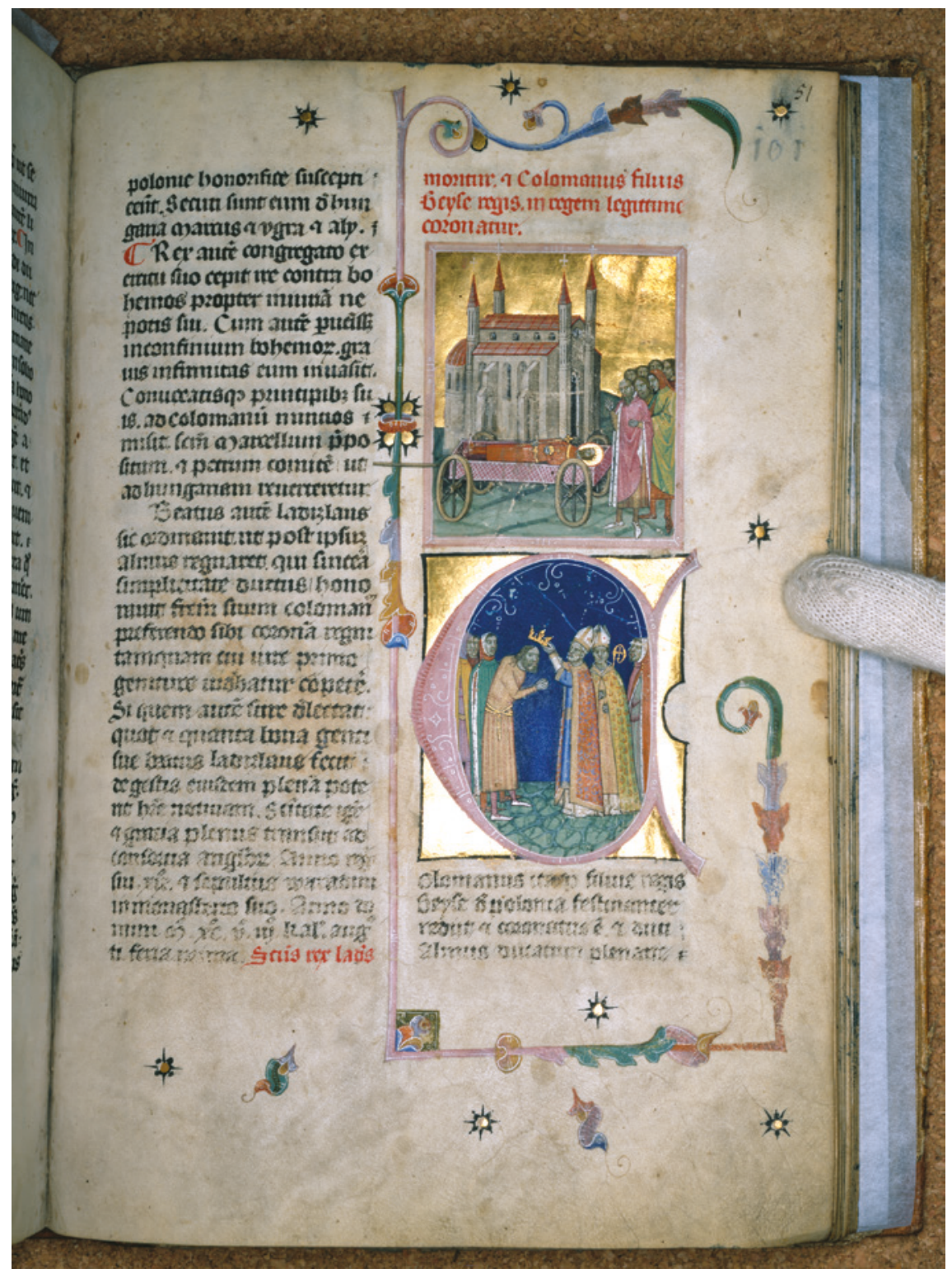

FIGURE 8.5 Budapest, Országos Széchényi Könyvtár, Cod. Lat. 404, fol. $5^{1 \mathrm{r}}$ (C) BUDAPEST, ORSZÁGOS SZÉCHÉNYI KÖNYVTÁR 


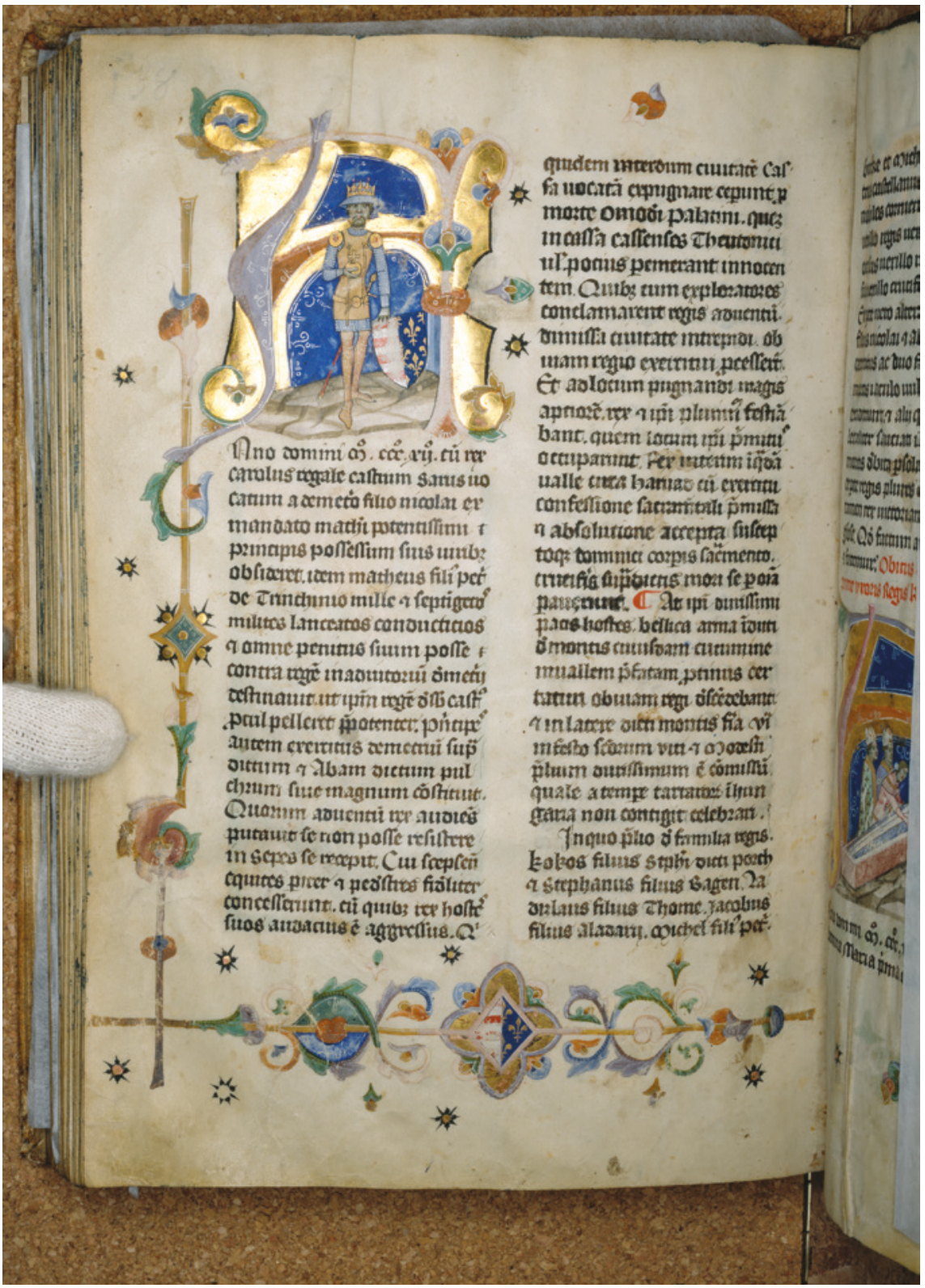

FIGURE 8.6 Budapest, Országos Széchényi Könyvtár, Cod. Lat. 404, fol. $69 \mathrm{v}$ (C) BUDAPEST, ORSZÁGOS SZÉCHÉNYI KÖNYVTÁR 